Depleted Uranium Investigation at Missile Impact Sites in White Sands Missile Range

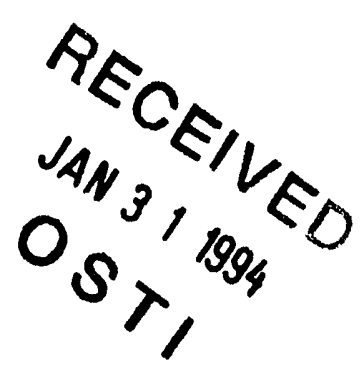

\section{Los Alamos \\ NATIONAL LABORATOAY}

Los Alamos National Laboratory is operated by the University of California for the United States Department of Energy under contract W-7405-ENG-36. 
This work was supported by the US Department of Defense, United States Army - White Sands Missile Range.

An Affirmative Action/Equal Opportunity Employer

This report was prepared as an account of work sponsored by an agencu of the United States Government. Neither The Regents of the University of Califormia, the' United State's Government nor any age'ncy thereof, nor any of their employees, makes any zourranty, express or implied, or assumes any legal liability or responstbility for the accuracy. completene's, ar usefulne'ss of any information, apparatus, product, or process disclosed, or represents that its use would not infringe prizately onened rights. Reference herein to any specific commercial product, process, or service by trade name, trademark, manufacturer, or otherweise, does not necesserily constitute or imply its e'ndorse'ment, recommendation, or fanoring by The Regents of the Uniersity of Californin. the United States Government, or any agency thereof. The vienes and opinions of authors expressed herein de not necessarily state' or reflect these of The Re'gents of

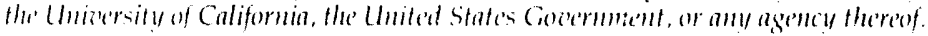


Depleted Uranium Investigation at Missile Impact Sites in White Sands Missile Range

D. M. Van Etten

W. D. Purtymun 


\section{ACKNOWLEDGEMENTS}

We thank Steve McLin for his support with the project and his fine work logging the drill core, Max Maes for his support with the drilling operation, and Belinda Harrigan for the illustrations and for putting this report togetner. 


\section{CONTENTS}

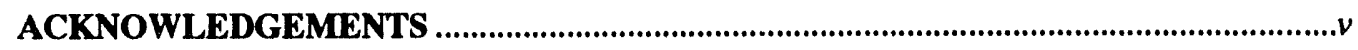

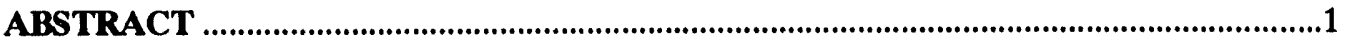

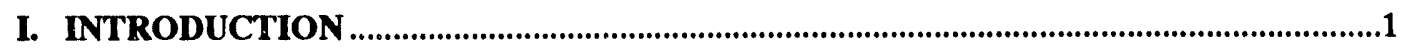

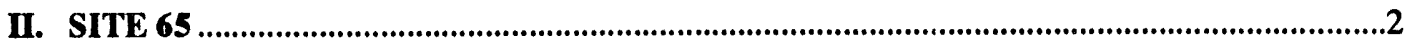

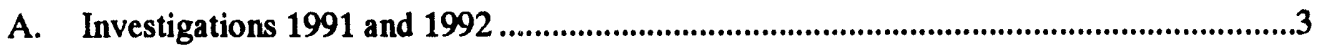

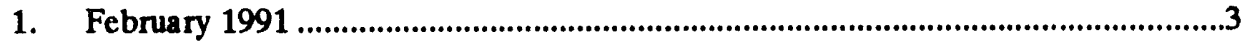

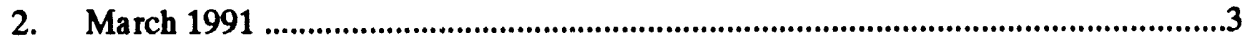

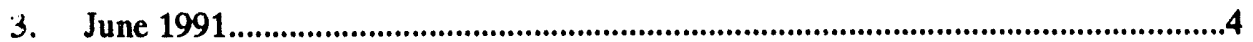

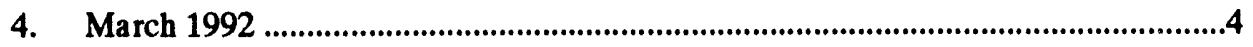

III. MISSILE IMPACT AREAS AT CHESS, SALT TARGET, AND MINE SITES ..............4

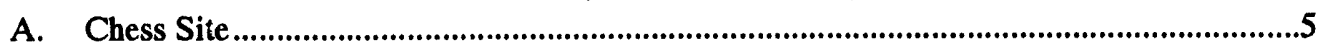

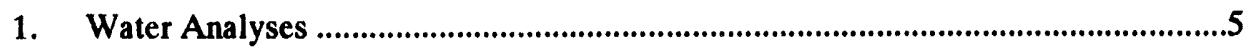

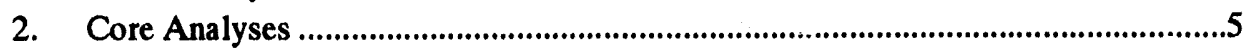

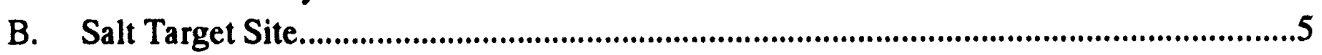

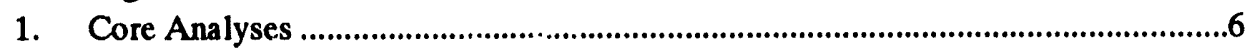

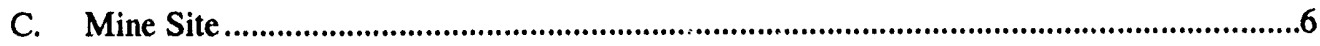

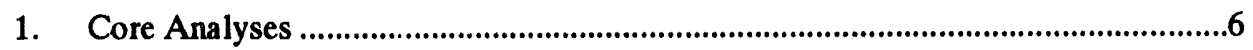

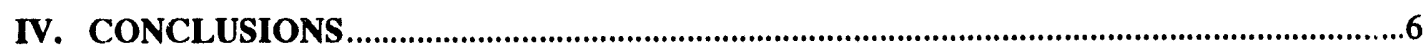

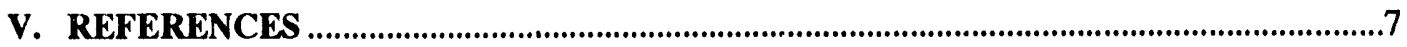




\section{TABLES}

Table 1. Uranium Analys ss from Miscellaneous Sources in or near

White Sands Missile Range

Table 2. Total Uranium and Ratio $\mathrm{U}^{235} / \mathrm{U}^{238}$ in Water from

Site 65 Monitoring Well

Table 3. Chemical and Miscellaneous Analyses of Water from

Site 65 Monitoring Well

Table 4. Chemical and Miscellaneous Analyses of Water from holes at Chess Site

Table 5. Total Uranium and Ratio $U^{235} / U^{238}$ from Test Holes at Chess Site ..................................13

Table 6. Total Uranium and Ratio $U^{235} / \mathrm{U}^{238}$ from Test Holes at Salt Site....................................14

Table 7. Total Uranium and Ratio $U^{235} / \mathrm{U}^{238}$ from Test Holes at Mine Site ....................................16

\section{ILLUSTRATIONS}

Fig. 1. Generalized location of Site 65, Chess, Salt, and Mine Sites on White Sands Missile Range in southern New Mexico

Fig. 2. Shaft containment above wa rhead compared to geologic log of monitoring well (well located $15 \mathrm{ft}$ to southeast of shaft)

Fig. 3. Well construction, water level (2-25-91), and pump setting on monitoring well Site 65

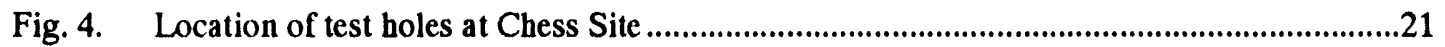

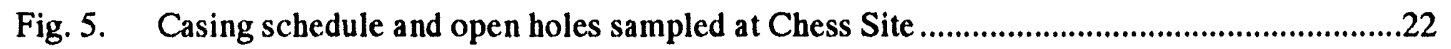

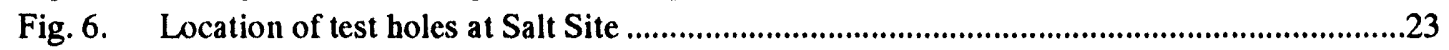

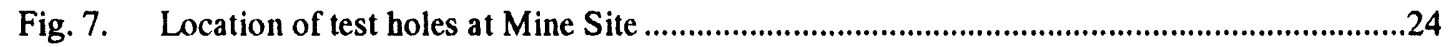

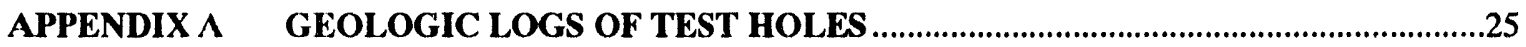




\title{
DEPLETED URANIUM INVESTIGATION AT MISSILE IMPACT SITES IN WHITE SANDS MISSILE RANGE
}

\author{
by
}

D. M. Van Etten and W. D. Purtymun

\begin{abstract}
An investigation for residual depleted uranium was conducted at Pershing missile impact sites on the White Sands Missile Range. Subsurface core soil samples were taken at Chess, Salt Target, and Mine Impact Sites. A sampling pump was installed in a monitoring well at Site 65 where a Pershing earth penetrator was not recovered. Pumping tests and water samples were taken at this site. Chess Site, located in a gypsum flat, was the only location showing elevated levels of depleted uranium in the subsurface soil or perched groundwater. Small fragments can still be found on the surface of the impact sites. The seasonal flooding and near surface water has aided in the movement of surface fragments.
\end{abstract}

\section{INTRODUCTION}

White Sands Missile Range (WSMR) requested site investigations of Pershing missile impact sites to determine the distribution, if any, of depleted uranium from the impact of the missile's earth penetrator. In most cases, the earth penetrator had been recovered and scrap resulting from the impact was cleaned up; however, small particles of depleted uranium may remain. Two types of investigation were undertaken.

The first study was conducted to determine the effect on an aquifer penetrated by a Pershing missile. The study was made at Site 65 where a Pershing earth penetrator containing depleted uranium was tested in June 1976. The missile penetrated the earth to a depth of about $200 \mathrm{ft}$ into an aquifer in the area. Recovery operations taken at the time were unsuccessful. A monitoring well was completed adjacent to the missile in August 1986 to monitor the aquifer. Part of the investigation involved installing a pump in the well and monitoring the aquifer to determine the quality of water with reference to depleted uranium.

Water from the aquifer was a nalyzed for total uranium and the ratio of ${ }^{235} U /{ }^{238} U$, to determine if depleted uranium was being leached from the weapon or fragments of the weapon. Uranium and the uranium ratios analyses were performed by Inductively Coupled Plasma Mass Spectrometry (ICPMS). Standard methods of analyses were performed to determine chemical quality of water. 
The second study was done to determine the distribution and concentration in the subsurface at impact sites of missile earth penetrators containing depleted uranium. The sites chosen were (a) Chess Site which is underlain by gypsum, (b) Salt Target Site which is underlain by anhydride and clays, and (c) Mine Site which is underlain by siltstones, sandstones, and occasional lens of limestone and gypsum. The earth penetrators had been recovered; however, some very small fragments of depleted uranium may still remain. The study obtained samples for analyses in the missile impact area. One core hole was located in the impact area of the weapon and several satellite holes were cored to assess the area adjacent to the actual earth penetrator impact point.

Cores from the impact area were analyzed using the ICPMS method for total uranium and the ratio of ${ }^{235} \mathrm{U} / 238 \mathrm{U}$. Cores from the satellite holes were analyzed for total uranium by Delayed Neutron Activation (DNA). The DNA analyses are not as sensitive as those done by ICPMS and are used for screening purposes.

Natural uranium occurs in all earth materials in varying concentrations according to rock type. Both the ICPMS and DNA methods of analyses for total uranium include the natural uranium. If fragments of depleted uranium are present in the sample, the reported concentration will be excessive. ICPMS analyses for the ratio of ${ }^{235} \mathrm{U} / 238 \mathrm{U}$ are used to determine depleted uranium. The normal ratios range from 0.0060 to 0.0080 or average about .0070 . Sa mples in the area ranged from $0.0076 \pm 0.0003$ to $0.0092 \pm 0.0020$ (Table 1). A report by Becker (Becker 1991) established the ratio to be $0.0072 \pm 0.0008$.

\section{SITE 65}

Site 65 is a missile impact site located in the southern part of the Missile Range near the center of the valley just north of U.S. Highway 70 (Fig. 1).

The background material in the following paragraphs was summarized from the U. S. Geological Survey (USGS) report on drilling and completion of a monitoring well at Site 65 (USGS 1986).

In June 1976, a Pershing D-38 Earth Penetrating Missile containing about $80 \mathrm{lbs}$ of depleted uranium impacted at the site. An investigation and recovery effort took place in 1977; however, there is no record of the outcome of the effort. The recovery operations included two test holes and a shaft sunk over the missile (Fig. 2). The shaft was sunk to the top of the earth penetrator at a depth of about $194 \mathrm{ft}$ and was cased with a $4 \mathrm{ft}$-diameter steel casing that extends about $2 \mathrm{ft}$ above land surface (LSD).

In August 1986 the USGS drilled a monitoring well about $15 \mathrm{ft}$ southeast of the shaft (Fig. 3). The hole was drilled using water ard a rock bit of 9-7/8 in. diameter. The well was cased with 4-in. diameter PVC plastic pipe.

During the recovery effort in 1977, a 4-ft diameter casing set above the earth penetrator was grouted in and backfilled with bentonite slurry to a depth of $122 \mathrm{ft}$. The casing was found to contain water to a depth of $95.9 \mathrm{ft}$ during a site visit in February 1991 (Fig. 2). The log indicates that the earth penetrator penetrated a sand that is saturated. The USGS indicated that the sand is probably part of a regional aquifer that moves to the southeast with a gradient of about $7.5 \mathrm{ft} / \mathrm{mile}$. 


\section{A. Investigation 1991 and 1992}

Site 65 was visited and data collected in February, March, and June of 1991, and in March of 1992.

\section{February 1991}

The site visit of February 25, 1991, was made to evaluate the conditions of the monitoring well with reference to installation of a pump. Water level in the monitoring well was $69.7 \mathrm{ft}$ below LSD. The depth of the well was determined to be $197 \mathrm{ft}$ below LSD. Seven $\mathrm{ft}$ of screen opening (190 to $197 \mathrm{ft}$ ) were left opposite the earth penetrator or impact area of the earth penetrator in the sand (Figs. 2 and 3).

Prior to determination of the depth of the well water, samples were collected at depths of $75,100,150$, 175,190 , and 197 (bottom) $\mathrm{ft}$ (Tables 1 and 2). The total uranium in the samples ranged from 17.2 to $19.4 \mu \mathrm{g} / \mathrm{L}$. The ratio ${ }^{235} \mathrm{U} / 238 \mathrm{U}$ ranged from 0.0061 to 0.0077 , within the range of natural uranium. There was no indication of the dispersion of depleted uranium from the earth penetrator or fragments of the earth penetrator in the sand and aquifer.

A water sample was also collected from the shaft at the bottom at a depth of $122 \mathrm{ft}$. The total dissolved uranium was $1 \mu \mathrm{g} / \mathrm{L}$ while the uranium concentrations were too low to determine the ratio of ${ }^{235} \mathrm{U} /{ }^{238} \mathrm{U}$. A background sample collected from a water tanker at the NASA operations strip indicated a total dissolved ura nium concentration of $1.9 \mu \mathrm{g} / \mathrm{L}$. Uranium concentrations were too low to determine ratios.

\section{March 1991}

During a site visit a small monitoring pump was installed in the well and sa mples were collected on March 19 and 20,1991. The pump is an air-driven bladder-type in which the water sample does not come in contact with the air. The pump was set at a depth of $180 \mathrm{ft}$, about $10 \mathrm{ft}$ above the top of the screens (Fig. 3). The pumping rate of the bladder pump is low, 0.5 gallons per minute (gpm).

Prior to setting the pump on March 19, an additional water sample was collected from the bottom of the hole with a bailer. The total uranium was $20.3 \mu \mathrm{g} / \mathrm{L}$ with a ${ }^{235} \mathrm{U} / 238 \mathrm{U}$ ratio of 0.0078 (Table 2).

The well was pumped for about 30 minutes removing about 15 gallons of water from the well. The total uranium was $15.2 \mu \mathrm{g} / \mathrm{L}$ with a ratio of 0.0088 (Table 2).

On March 20 the well was pumped for 70 minutes with about 35 gallons of water removed from the well. The water level declined from 68.7 to $73.8 \mathrm{ft}$. The water coming through the screen section was muddy. Samples were collected at 50,60, and 70 minutes of pumping (Table 2).

A water sample taken 20 minutes prior to fresh water entering the pump from the screen section was $14.3 \mu \mathrm{g} / \mathrm{L}$ with a ${ }^{235} \mathrm{U} / 238 \mathrm{U}$ ratio of 0.0070 (Table 2). At 40 minutes to 70 minutes, when water was muddy, the total uranium ranged from 14.2 to $15.2 \mu \mathrm{Ci} / \mathrm{L}$ with ${ }^{235} \mathrm{U} / 238 \mathrm{U}$ ratios of 0.0075 to 0.0085 . The uranium levels and ratios indicate uranium in water pumped from the well is natural.

The suspended solids were filtered from the samples collected at 60 and 70 minutes and were analyzed for total uranium in the suspended sediments. The total uranium reported was 5.0 and $5.8 \mu \mathrm{g} / \mathrm{L}$ (Table 2). 
Analyses of the drawdown and recovery of the water level of this pumping period indicated that the sand unit has a coefficient of permeability of about 8 gallons per day/sq $\mathrm{ft}$. With a gradient of $7.5 \mathrm{ft} / \mathrm{mile}$, the velocity of movement in the aquifer is very slow, probably in the range of 15 to $25 \mathrm{ft} /$ year.

\section{June 1991}

The monitoring well was sampled again on June 12, 1991. The samples were collected at 5, 120, and 130 minutes of pumping (Table 2). Total uranium ranged from 14.2 to $14.8 \mu \mathrm{g} / \mathrm{L}$ in the range of natural ura nium.

The chemical quality of water determined from three samples indicated the water was of a sodiumsulfate type with high chlorides. The total dissolved solids were high, ranging from 4,000 to 4,800 milligrams/L. The water quality is typical for the area in part due to the underlying or adjacent gypsum formation (Table 3 ).

\section{March 1992}

The monitoring well was sampled again on March 7, 1992. The well was pumped for a 9 hour period at a rate of about $0.65 \mathrm{gpm}$. The water level declined from $70 \mathrm{ft}$ at the start of the test to $76.5 \mathrm{ft}$ when the last sample was taken. Sixteen water samples were collected during the nine hours of pumping. The total uranium was about $11 \mu \mathrm{g} / \mathrm{L}$ during the first 30 minutes of pumping and declined to range from 7.1 to 9.1 $\mu \mathrm{g} / \mathrm{L}$. The ura nium ratio varied from sample to sample; however, with the error term, remained within the range of natural uranium with a average of $0.0072 \pm 0.0008$ (Table 2).

\section{Missile Impact Areas at Chess, Salt Target, and Mine Sites}

Subsurface investigations were made at individual missile impact areas at these three sites by collecting cores from select depth intervals. The cores were collected using a continuous coring within an auger. The auger removed the excess cuttings and the samples taken came in contact with only the core barrel. No fluids, water or air, were used in the coring operations. The core runs are $5 \mathrm{ft}$ in depth. Core barrels are decontaminated after each core run before being used again.

At each of the three sites, the missile earth penetrator had been recovered. The depth of penetration was $20 \mathrm{ft}$ or less. All scrap and fragments of the missile were collected and the excavation was filled with soil or material excavated from the hole. The initial hole was cored at this impact area, in the refilled excavated material. On the surface, small fragments of metal, wire, plastic, and scrap remain as a result of the missile impact. Visual examination of the surface at the sites indicated only small fragments of depleted uranium (less than 0.25 -in dia) at Salt Site.

Five boles were drilled at each site, one in the impact area and four adjacent holes north, east, south, and west of the impact area hole. The distances of the four adjacent holes varied from the impact hole, allowing for the direction of the missile fragments after impact. In addition, background holes were cored at a distance from the main area of investigation to allow comparison of the analytical results. The cores were logged, at which time visual inspection did not detect any debris fragments, metal, plastic, or depleted uranium in the cores either from the hole cored in the impact (refilled area) or from the satellite holes. The geologic logs of cores described during coring operations are found in Appendix $\mathbf{A}$. 


\section{A. Chess Site}

Chess Site is located in a gypsum flat and is underlain by an unknown thickness of gypsum. The site is in the lower part of the valley north of White Sands National Monument and south of the NASA landing strip (Fig. 1).

Five holes were cored at and adjacent to the impact area (Fig. 4). The holes ranged in depth from 9 to $28 \mathrm{ft}$. Water was encountered in all the holes at a depth of 6 to $10 \mathrm{ft}$. Two of the holes were cased as observation wells and two, including the background hole located about $400 \mathrm{ft}$ to the north, were left uncased to allow for collection of water samples (Fig. 5). The other two holes were plugged and abandoned.

\section{Water Analyses}

On June 18, 1991, four water samples were collected from the test holes in and adjacent to the impact area and one sample was collected from the background hole. Two volumes of water were removed from the cased holes prior to the collection of samples (Holes CI-Hole and N-Hole). Hole CI-Hole was bailed dry and a second sample collected. The two uncased holes, S-Hole and Bkg-Hole, were also sampled.

The chemical quality of water from the three holes is a predominate sodium-sulfate with high chlorides that is typical of the gypsum where the water was encountered. The concentration of total dissolved solids is high, ranging from 10,000 to about 40,000 milligrams/L. The variations in concentrations in some of the chemical constituents are due in part to cased or uncased holes where the concentrations are elevated; the error terms are enlarged to as much as $20 \%$ (Table 4 ).

The total uranium in the water was high, ranging from a low of about 13 (one sample) to $4 \mathfrak{G} y \mu \mathrm{g} / \mathrm{L}$. If the chemistry for the sample would support ratios of ${ }^{235} \mathrm{U} /{ }^{238} \mathrm{U}$, the measurement would determine if the elevated uranium is natural or from missile fragments. Ratios of 0.0017 (S-Hole), 0.0037 (N-Hole), and 0.0051 (CI-Hole, impact hole) indicate depleted uranium from the missile fragments (Table 4). The uranium was leached from the missile fragments and is moving with the water in the gypsum.

\section{Core Analyses}

The total uranium from the background hole averaged $1.3 \mu \mathrm{g} / \mathrm{g}$ while the ratios averaged 0.0079 . The total uranium in the impact hole (Cl-Hole) was elevated near the surface at $16 \mu \mathrm{g} / \mathrm{g}$ (Table 5). The ratios in the upper two samples, 3 and $8 \mathrm{ft}$, were 0.0002 and 0.0058 respectively indicating some depleted uranium from missile fragments. The total uranium in S-Hole was slightly elevated with some concentrations ranging from 3 to $5 \mu \mathrm{g} / \mathrm{g}$. Both the cores and water from S-Hole were above natural levels, indicating the presence of depleted uranium fragments in and adjacent to the impact area.

\section{B. Salt Target Site}

Salt Target Site is located near the center of the missile range (Fig. 1). The site is underlain by silts, clays, and anhydrides. No water or excessive moisture was encountered in coring in the area. Five boles were cored at the site (Fig. 6). The holes ranged in depth from 24 to $29 \mathrm{ft}$. Two background holes were cored about $500 \mathrm{ft}$ to the northwest. 


\section{Core Analyses}

Total uranium in the cores from the background hole averaged $1.4 \mu \mathrm{g} / \mathrm{g}$ while the average ratios were 0.0080 , in the range of natural uranium. No significant difference in the concentrations of total uranium and ratios in the S-Hole (impact area) and the total uranium in the satellite boles SW-Hole, SE-Hole, NE-Hole, and NW-Hole was found when compared to the data from the background hole (Table 6). Depleted uranium from the missile impact was not detected upon analyses of the core.

\section{Mine Site}

Mine Site is located in the north end of the missile range (Fig. 1). The site is underlain by silts, clays, sandstones, and limestone lens. Four holes were cored at the site (Fig. 7) in areas that would reflect the maximum effect of the impacted missile. The core holes ranged from 29 to $49 \mathrm{ft}$ in depth. The background hole is located about $600 \mathrm{ft}$ to the west. The holes were dry and moisture content was at a minimum.

\section{Core Analyses}

Total uranium concentration in cores from the background hole was $1.0 \mu \mathrm{g} / \mathrm{g}$ while the average ratio was 0.0074 . S-Hole (impact area) average total uranium was $1.3 \mu \mathrm{g} / \mathrm{g}$ with a ratio of 0.0088 which is in the range of natural uranium. The total uranium from cores from E-Hole, C-Hole, and W-Hole indicated no depleted uranium from the impact of the missile in the area (Table 7).

\section{CONCLUSIONS}

Ana lysis of water samples from the aquifer adjacent to the missile at Site 65 showed that uranium in the aquifer was natural and no dispersion of depleted uranium from the earth penetrator or fragments of the earth penetrator was indicated.

Water and core samples from Chess Site indicated that missile fragments were present in the area and that water encountered in the hole was contaminated with depleted uranium leached from the missile earth penetrator or fragments.

Concentrations of total uranium and uranium ratios from cores from test holes at Salt and Mine Sites showed only natural uranium with no indication of depleted uranium in samples collected at these sites. 


\section{REFERENCES}

Becker 1991: Becker, N. M., "Influence of Hydraulic and Geomorphology Components of Semi-Arid Watershed on Depleted Uranium Transport," Doctoral Thesis, University of Wisconsin-Madison (1991).

USGS 1986: U. S. Geological Survey, "Depleted Uranium Monitoring Well, Site 65, White Sands Missile Range," Administrative Report to WSMR, Las Cruces, N. M. (1986). 
Table 1. Uranium Analyses from Miscellaneous Sources in or near White Sands Missile Range.

\begin{tabular}{lrc} 
Source & $\begin{array}{c}\text { Total } \mathrm{U} \\
(\mu \mathrm{g} / \mathrm{L})\end{array}$ & \multicolumn{1}{c}{$\begin{array}{c}\text { Ratio } \\
235 \mathrm{U} /{ }^{238} \mathrm{U}\end{array}$} \\
\hline & & \\
Main Post & $1.5 \pm 0.2$ & \\
White Sands Monument & $2.3 \pm 0.2$ & $0.0092 \pm 0.0020$ \\
HELSTF & $3.1 \pm 0.2$ & $0.0076 \pm 0.0003$ \\
HTA Well & $77.8 \pm 3.9$ & \\
Site 65 Shaft ${ }^{\mathrm{b}}(2 / 25 / 91)$ & $1.0 \pm 0.2$ & \\
Water from Tank-NASA & & \\
Operation Strip (2/25/91) & $1.9 \pm 0.2$ & \\
\hline
\end{tabular}

${ }^{2} 235 \mathrm{U}$ concentration too low to measure.

'Sample bailed from $4 \mathrm{ft}$ diameter shaft bottom at $122 \mathrm{ft}$; water level $95.1 \mathrm{ft} \mathrm{LSD} \mathrm{2/25/91.}$ 
Table 2. Total Uranium and Ratio ${ }^{235} \mathrm{U} /{ }^{238} \mathrm{U}$ in Water from Site 65 Monitoring Well."

February 25, $1991^{b}$

\begin{tabular}{ccc}
$\begin{array}{c}\text { Depth } \\
(\mathrm{ft})\end{array}$ & $\begin{array}{c}\text { Total } \mathrm{U} \\
(\mu \mathrm{g} / \mathrm{L})\end{array}$ & $\begin{array}{c}\text { Ratio } \\
\text { 235U/238U }\end{array}$ \\
\hline & & \\
75 & $17 \pm 0.8$ & $0.0072 \pm 0.0002$ \\
100 & $19 \pm 1.0$ & $0.0075 \pm 0.0017$ \\
150 & $17 \pm 0.9$ & $0.0065 \pm 0.0009$ \\
175 & $16 \pm 0.8$ & $0.0061 \pm 0.0024$ \\
190 & $18 \pm 0.9$ & $0.0077 \pm 0.0007$ \\
197 & $18 \pm 0.9$ & $0.0077 \pm 0.0009$ \\
$x$ & $17.5 \pm 1.1$ & \\
& & $0.0071 \pm 0.0007$
\end{tabular}

March 19, 1991

Pumped

Total U

Ratio

(min)

$(\mu \mathrm{g} / \mathrm{L})$

${ }^{235} \mathrm{U} / 238 \mathrm{U}$

Bailed

$20 \pm 0.8$

$0.0078 \pm 0.0004$

Pumped $30 \mathrm{~min}$

$15 \pm 0.6$

$0.0088 \pm 0.0005$

$\bar{x}$

$17.5 \pm 3.5$

$0.0083 \pm 0.0007$

March 20, 1991

Pumped

Total U

Ratio

(min)

$(\mu \mathrm{g} / \mathrm{L})$

${ }^{235} \mathrm{U} / 238 \mathrm{U}$

20

40

$14 \pm 0.6$

$15 \pm 0.6$

$15 \pm 0.6$

$15 \pm 0.6$

$14 \pm 0.6$

$0.0070 \pm 0.0015$

50

60

$0.0075 \pm 0.0005$

$0.0085 \pm 0.0005$

70

$14.6 \pm 0.6$

$0.0077 \pm 0.0010$

$0.0083 \pm 0.0002$

$\bar{x}$

$0.0078 \pm 0.0006$

June 17, 1991

Pumped

Total U

(min)

$(\mu \mathrm{g} / \mathrm{L})$

5
120
130

$14.2 \pm 0.7$

120

$14.7 \pm 0.8$

130

$14.8 \pm 0.6$

$\bar{x}$

$14.6 \pm 0.3$ 
Table 2. (Cont.)

\begin{tabular}{ccc}
$\begin{array}{c}\text { March } 7,1992 \\
\begin{array}{c}\text { Pumped } \\
(\mathrm{min})\end{array}\end{array}$ & $\begin{array}{c}\text { Total } \mathrm{U} \\
(\mu \mathrm{g} / \mathrm{L})\end{array}$ & $\begin{array}{c}\text { Ratio } \\
235 \mathrm{U} / 238 \mathrm{U}\end{array}$ \\
\hline & & \\
14 & $11.5 \pm 1.2$ & $0.0083 \pm 0.0010$ \\
30 & $11.1 \pm 1.1$ & $0.0071 \pm 0.0002$ \\
60 & $8.6 \pm 0.9$ & $0.0068 \pm 0.0012$ \\
90 & $8.9 \pm 0.9$ & $0.0068 \pm 0.0011$ \\
120 & $9.1 \pm 0.9$ & $0.0067 \pm 0.0016$ \\
150 & $8.5 \pm 0.9$ & $0.0082 \pm 0.0007$ \\
180 & $9.0 \pm 0.9$ & $0.0068 \pm 0.0009$ \\
210 & $9.1 \pm 0.9$ & $0.0072 \pm 0.0004$ \\
330 & $8.0 \pm 0.8$ & $0.0064 \pm 0.0013$ \\
360 & $7.4 \pm 0.7$ & $0.0087 \pm 0.0013$ \\
390 & $7.1 \pm 0.7$ & $0.0071 \pm 0.0012$ \\
420 & $7.6 \pm 0.8$ & $0.0058 \pm 0.0010$ \\
450 & $7.8 \pm 0.8$ & $0.0078 \pm 0.0010$ \\
480 & $7.7 \pm 0.8$ & $0.0078 \pm 0.0017$ \\
510 & $7.7 \pm 0.8$ & $0.0070 \pm 0.0006$ \\
540 & $7.8 \pm 0.8$ & $0.0074 \pm 0.0002$ \\
& & \\
$\bar{x}$ & $8.6 \pm 1.2$ & $0.0072 \pm 0.0008$
\end{tabular}

${ }^{a}$ Analyses by inductively coupled plasma mass spectrometry (ICPMS).

bSamples bailed from select zones for background prior to installation of pump. 
Table 3. Chemical and Miscellaneous Analyses of Water from Site 65 Monitoring Well.

$\begin{array}{ccc}\text { Pumped } & \text { Pumped } & \text { Pumped } \\ 5 \mathrm{~min} & 120 \mathrm{~min} & 130 \mathrm{~min}\end{array}$

Chemical Analyses

$(m g / L)$

$\begin{array}{lrrr}\mathrm{SiO}_{2} & 30 & 28 & 28 \\ \mathrm{Ca} & 420 & 470 & 470 \\ \mathrm{Mg} & 140 & 150 & 150 \\ \mathrm{~K} & 9 & 9 & 10 \\ \mathrm{Na} & 790 & 930 & 880 \\ \mathrm{Cl} & 285 & 358 & 346 \\ \mathrm{~F} & - & 1 & - \\ \text { Total } & & & \\ \text { Alkalinity } & 81 & 70 & 82 \\ \mathrm{SO}_{4} & 3600 & 3700 & 3600 \\ \mathrm{NO}_{3}-\mathrm{N} & 4 & 5 & 4 \\ \mathrm{TDS} & 4000 & 4800 & 4500 \\ \text { Total } & & & \\ \mathrm{Hardness} & 1625 & 1791 & 1791 \\ \text { pH } & - & 8 & -\end{array}$

Miscellaneous Analyses

$\begin{array}{lccc}\text { Thorium }(\mu \mathrm{g} / \mathrm{L}) & 1.2 \pm 1.0 & 2.4 \pm 1.0 & 1.0 \pm 1.0 \\ \text { Tritium }(\mathrm{pCi} / \mathrm{L}) & 700.0 \pm 300 & 600.0 \pm 300.0 & 300.0 \pm 300.0 \\ \text { Total } \mathrm{U}(\mu \mathrm{g} / \mathrm{L}) & 14.8 \pm 0.6 & 14.2 \pm 0.7 & 14.7 \pm 0.8 \\ \text { Ratio } 235 \mathrm{U} / 238 \mathrm{U} & - & & \end{array}$

${ }^{2} 235 U$ concentration too low to measure. 
Table 4. Chemical and Miscellaneous Analyses of Water from Holes at Chess Site.

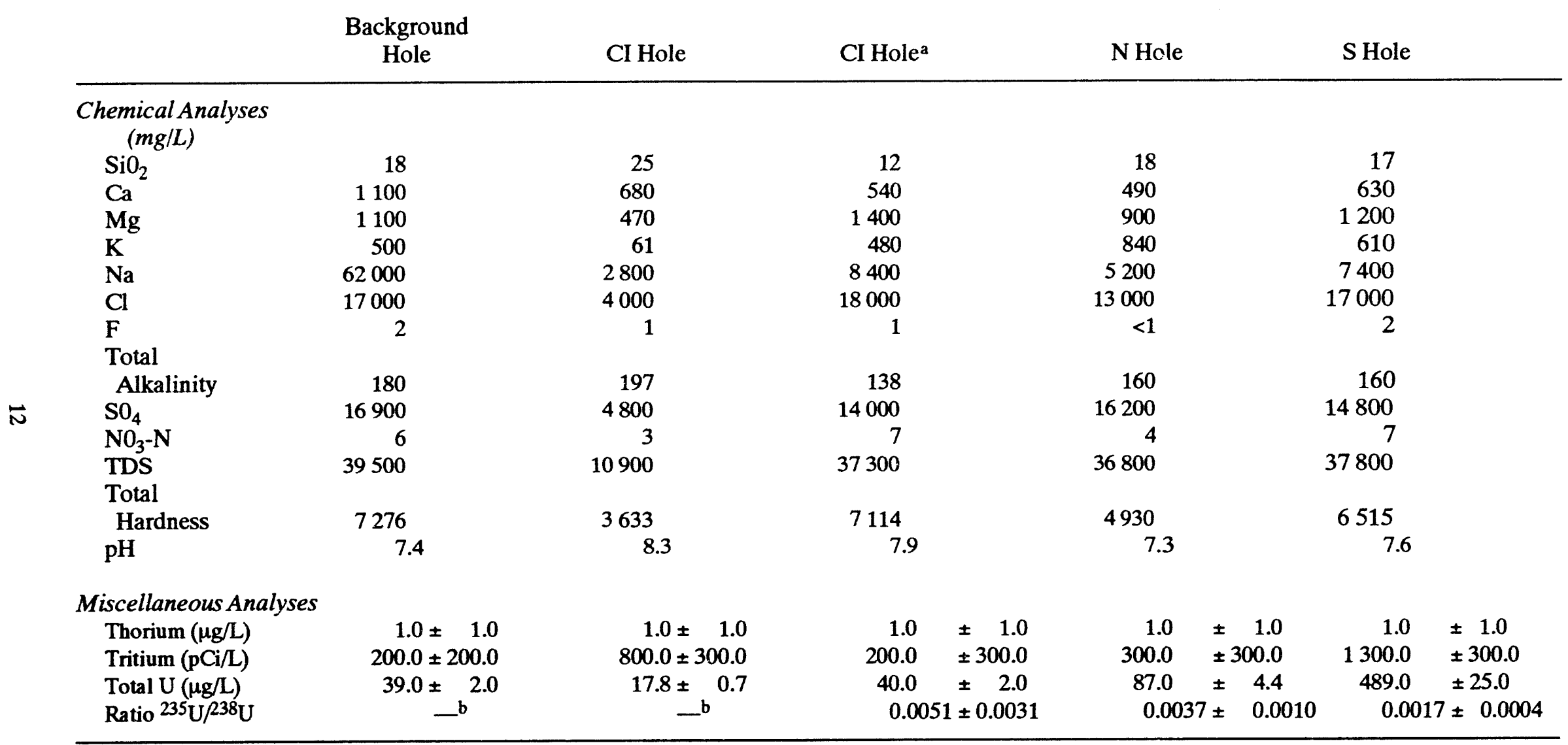

aHole bailed dry, sample taken after well recovered.

${ }^{b 235} \mathrm{U}$ concentration too low to measure. 
Table 5. Total Uranium and Ratio ${ }^{235} \mathrm{U} /{ }^{238} \mathrm{U}$ from Test Holes at Chess Site.

\section{Background Hole}

\begin{tabular}{ccc}
$\begin{array}{c}\text { Depth } \\
(\mathrm{ft})\end{array}$ & $\begin{array}{c}\text { Total U } \\
(\mu \mathrm{g} / \mathrm{g})\end{array}$ & $\begin{array}{c}\text { Ratio } \\
235 \mathrm{U} / 33 \mathrm{U}\end{array}$ \\
\hline 4 & $0.63 \pm 0.06$ & $0.0096 \pm 0.0017$ \\
9 & $0.98 \pm 0.10$ & $0.0083 \pm 0.0020$ \\
14 & $1.40 \pm 0.14$ & $0.0083 \pm 0.0010$ \\
19 & $0.84 \pm 0.08$ & $0.0076 \pm 0.0034$ \\
24 & $1.80 \pm 0.18$ & $0.0068 \pm 0.0008$ \\
29 & $1.90 \pm 0.52$ & $0.0068 \pm 0.0020$ \\
& & \\
$\bar{x}$ & $1.30 \pm 0.52$ & $0.0079 \pm 0.0011$
\end{tabular}

CI Hole (Impact Area)

\begin{tabular}{ccc}
$\begin{array}{c}\text { Depth } \\
(\mathrm{ft})\end{array}$ & $\begin{array}{c}\text { Total } \mathrm{U} \\
(\mu \mathrm{g} / \mathrm{g})\end{array}$ & $\begin{array}{c}\text { Ratio } \\
235 \mathrm{U} / 238 \mathrm{U}\end{array}$ \\
\hline 3 & $16.0 \pm 1.60$ & $0.0019 \pm 0.0002$ \\
8 & $1.4 \pm 0.14$ & $0.0058 \pm 0.0019$ \\
13 & $2.0 \pm 0.20$ & $0.0064 \pm 0.0006$ \\
18 & $1.5 \pm 0.15$ & $0.0074 \pm 0.0008$ \\
23 & $1.9 \pm 0.19$ & $0.0074 \pm 0.0004$ \\
& & \\
$\bar{x}$ & $4.6 \pm 6.40$ & $0.0058 \pm 0.0023$
\end{tabular}

\section{$S$ Hole}

\begin{tabular}{cc}
$\begin{array}{c}\text { Depth } \\
(\mathrm{ft})\end{array}$ & $\begin{array}{c}\text { Total } \mathrm{U} \\
(\mu \mathrm{g} / \mathrm{g})\end{array}$ \\
\hline 3 & $4.0 \pm 0.40$ \\
8 & $5.0 \pm 0.50$ \\
13 & $3.0 \pm 0.40$ \\
18 & $0.6 \pm 0.06$ \\
23 & $3.0 \pm 0.30$ \\
28 & $2.0 \pm 0.20$ \\
& $2.9 \pm 1.50$
\end{tabular}

N Hole

\begin{tabular}{cc}
$\begin{array}{c}\text { Depth } \\
(\mathrm{ft})\end{array}$ & $\begin{array}{c}\text { Total U } \\
(\mu \mathrm{g} / \mathrm{g})\end{array}$ \\
\hline 4 & $1.0 \pm 0.10$ \\
9 & $1.0 \pm 0.20$ \\
& \\
$x$ & $1.0 \pm 0.00$
\end{tabular}

\section{E Hole}

\begin{tabular}{cc}
$\begin{array}{c}\text { Depth } \\
(\mathrm{ft})\end{array}$ & $\begin{array}{c}\text { Total U } \\
(\mu \mathrm{g} / \mathrm{g})\end{array}$ \\
\hline 4 & $0.9 \pm 0.1$ \\
9 & $1.0 \pm 0.1$ \\
14 & $0.6 \pm 0.1$ \\
16 & $1.0 \pm 0.2$ \\
& \\
$\bar{x}$ & $0.9 \pm 0.2$
\end{tabular}

W Hole

\begin{tabular}{cc}
$\begin{array}{c}\text { Depth } \\
(\mathrm{ft})\end{array}$ & $\begin{array}{c}\text { Total U } \\
(\mu \mathrm{g} / \mathrm{g})\end{array}$ \\
\hline 4 & $1.0 \pm 0.2$ \\
9 & $2.0 \pm 0.2$ \\
14 & $2.0 \pm 0.2$ \\
18 & $1.0 \pm 0.2$ \\
& \\
$x$ & $1.5 \pm 0.6$
\end{tabular}


Table 6. Total Uranium and Ratio ${ }^{235} U /{ }^{238} U$ from Test Holes at Salt Site.

Background Hole

Deplh

(fi)
Total U

$(\mu \mathrm{g} / \mathrm{g})$
Ratio ${ }^{235} \mathrm{U} / 238 \mathrm{U}$

\begin{tabular}{rll}
\hline 4 & $0.85 \pm 0.09$ & $0.0084 \pm 0.0029$ \\
9 & $0.79 \pm 0.08$ & $0.0082 \pm 0.0014$ \\
14 & $1.80 \pm 0.18$ & $0.0086 \pm 0.0011$ \\
19 & $2.40 \pm 0.24$ & $0.0073 \pm 0.0019$ \\
24 & $1.30 \pm 0.13$ & $0.0068 \pm 0.0015$ \\
29 & $1.30 \pm 0.13$ & $0.0077 \pm 0.0010$ \\
34 & $1.10 \pm 0.11$ & $0.0083 \pm 0.0011$ \\
39 & $0.50 \pm 0.05$ & $0.0087 \pm 0.0012$ \\
$\bar{x}$ & $1.40 \pm 0.57$ & \\
& &
\end{tabular}

S Hole (Impact Area)

Depth

(ft)
Total U

$(\mu \mathrm{g} / \mathrm{g})$
Ratio ${ }^{235} \mathrm{U} / 238 \mathrm{U}$

$\begin{array}{rll}4 & 1.50 \pm 0.15 & 0.0084 \pm 0.0004 \\ 9 & 1.50 \pm 0.15 & 0.0085 \pm 0.0019 \\ 14 & 1.80 \pm 0.20 & 0.0082 \pm 0.0022 \\ 19 & 3.60 \pm 0.40 & 0.0076 \pm 0.0011 \\ 24 & 0.35 \pm 0.04 & 0.0084 \pm 0.0014 \\ 29 & 0.94 \pm 0.09 & 0.0095 \pm 0.0007 \\ \bar{x} & & \\ & 1.60 \pm 1.10 & 0.0084 \pm 0.0006\end{array}$

SW Hole

Depth

(fi)

$\begin{array}{rr}4 & 2.0 \pm 0.20 \\ 9 & 1.0 \pm 0.10 \\ 14 & 2.0 \pm 0.20 \\ 19 & 3.0 \pm 0.30 \\ 24 & 0.6 \pm 0.06 \\ 29 & 0.1 \pm 0.01 \\ & \\ \bar{x} & 1.5 \pm 1.10\end{array}$

\section{SE Hole}

Depth

(ft)

Total U $(\mu \mathrm{g} / \mathrm{g})$

\begin{tabular}{rl}
\hline 4 & $2.0 \pm 0.20$ \\
14 & $2.0 \pm 0.20$ \\
19 & $3.0 \pm 0.30$ \\
24 & $0.6 \pm 0.06$ \\
& \\
$\bar{x}$ & $1.9 \pm 1.00$
\end{tabular}


Table 6. (Cont.)

\section{NE Hole}

Depth

(ft)

\begin{tabular}{rl}
\hline 4 & $2.0 \pm 0.20$ \\
9 & $2.0 \pm 0.20$ \\
14 & $2.0 \pm 0.20$ \\
19 & $3.0 \pm 0.30$ \\
24 & $0.5 \pm 0.05$ \\
29 & $1.0 \pm 0.10$ \\
& \\
$\bar{x}$ & $1.8 \pm 0.88$
\end{tabular}

\section{NW Hole}

Depth

(ft)

Total U

$(\mu \mathrm{g} / \mathrm{g})$

$0.4 \pm 0.04$

$2.0 \pm 0.20$

$2.0 \pm 0.20$

$3.0 \pm 0.30$

$5.0 \pm 0.50$

$1.0 \pm 0.10$

$2.2 \pm 1.60$ 
Depleted Uranium Investigation at Missile

Impact Sites in White Sands Missile Range

Table 7. Total Uranium and Ratio ${ }^{235} \mathrm{U} /{ }^{238} \mathrm{U}$ from Test Holes at Mine Site.

Background Hole

\begin{tabular}{ccc}
$\begin{array}{c}\text { Depth } \\
(\mathrm{ft})\end{array}$ & $\begin{array}{c}\text { Total } \mathrm{U} \\
(\mu \mathrm{g} / \mathrm{g})\end{array}$ & $\begin{array}{c}\text { Ratio } \\
235 \mathrm{U} / 238 \mathrm{U}\end{array}$ \\
\hline 4 & $1.20 \pm 0.10$ & $0.0073 \pm 0.0013$ \\
9 & $0.74 \pm 0.07$ & $0.0102 \pm 0.0038$ \\
14 & $0.65 \pm 0.07$ & $0.0072 \pm 0.0014$ \\
19 & $0.75 \pm 0.08$ & $0.0063 \pm 0.0011$ \\
24 & $0.90 \pm 0.09$ & $0.0073 \pm 0.0008$ \\
29 & $1.10 \pm 0.11$ & $0.0078 \pm 0.0010$ \\
34 & $0.74 \pm 0.07$ & $0.0065 \pm 0.0022$ \\
39 & $0.71 \pm 0.07$ & $0.0062 \pm 0.0016$ \\
44 & $1.80 \pm 0.18$ & $0.0078 \pm 0.0004$ \\
49 & $1.70 \pm 0.17$ & $0.0075 \pm 0.0004$ \\
& & \\
$\bar{x}$ & $1.03 \pm 0.42$ & $0.0074 \pm 0.0011$
\end{tabular}

S Hole (Impact Area)

\begin{tabular}{ccc}
$\begin{array}{c}\text { Deplh } \\
\text { (ii) }\end{array}$ & $\begin{array}{c}\text { Total } U \\
(\mu \mathrm{g} / \mathrm{g})\end{array}$ & $\begin{array}{c}\text { Ratio } \\
235 \mathrm{U} / 38 \mathrm{U}\end{array}$ \\
\hline 4 & $0.83 \pm 0.08$ & $0.0085 \pm 0.0038$ \\
9 & $0.84 \pm 0.08$ & $0.0100 \pm 0.0032$ \\
14 & $0.87 \pm 0.09$ & $0.0118 \pm 0.0010$ \\
19 & $1.20 \pm 0.10$ & $0.0095 \pm 0.0007$ \\
24 & $1.20 \pm 0.12$ & $0.0079 \pm 0.0007$ \\
29 & $1.20 \pm 0.12$ & $0.0095 \pm 0.0010$ \\
34 & $1.20 \pm 0.11$ & $0.0073 \pm 0.0014$ \\
39 & $1.20 \pm 0.10$ & $0.0072 \pm 0.0009$ \\
44 & $1.80 \pm 0.18$ & $0.0085 \pm 0.0005$ \\
49 & $2.30 \pm 0.20$ & $0.0076 \pm 0.0009$ \\
& & \\
$\bar{x}$ & $1.26 \pm 0.46$ & $0.0088 \pm 0.0014$
\end{tabular}

\section{E Hole}

\begin{tabular}{cc}
$\begin{array}{c}\text { Depth } \\
\text { (ii) }\end{array}$ & $\begin{array}{c}\text { Total U } \\
(\mu \mathrm{g} / \mathrm{g})\end{array}$ \\
\hline 4 & $2.0 \pm 0.20$ \\
9 & $1.0 \pm 0.10$ \\
14 & $1.0 \pm 0.10$ \\
19 & $1.0 \pm 0.10$ \\
24 & $1.0 \pm 0.10$ \\
29 & $1.0 \pm 0.10$ \\
& \\
$\bar{x}$ & $1.2 \pm 0.41$
\end{tabular}

\section{Hole}

\begin{tabular}{cc}
$\begin{array}{c}\text { Depth } \\
(\mathrm{ft})\end{array}$ & $\begin{array}{c}\text { Total } \mathrm{U} \\
(\mu \mathrm{g} / \mathrm{g})\end{array}$ \\
\hline 4 & $2.0 \pm 0.20$ \\
9 & $1.0 \pm 0.10$ \\
14 & $1.0 \pm 0.10$ \\
19 & $1.0 \pm 0.10$ \\
24 & $2.0 \pm 0.20$ \\
29 & $1.0 \pm 0.10$ \\
34 & $1.0 \pm 0.10$ \\
39 & $2.0 \pm 0.20$ \\
& \\
$\bar{x}$ & $1.4 \pm 0.52$
\end{tabular}


Table 7. (Cont.)

W Hole

Depth

Total U

(ft)

$(\mu \mathrm{g} / \mathrm{g})$

4

$2.0 \pm 0.20$

9

$1.0 \pm 0.10$

14

$1.0 \pm 0.10$

19

$1.0 \pm 0.10$

24

$2.0 \pm 0.20$

29

34

$1.0 \pm 0.10$

$1.0 \pm 0.10$

39

$2.0 \pm 0.20$

$\bar{x}$

$1.4 \pm 0.52$ 


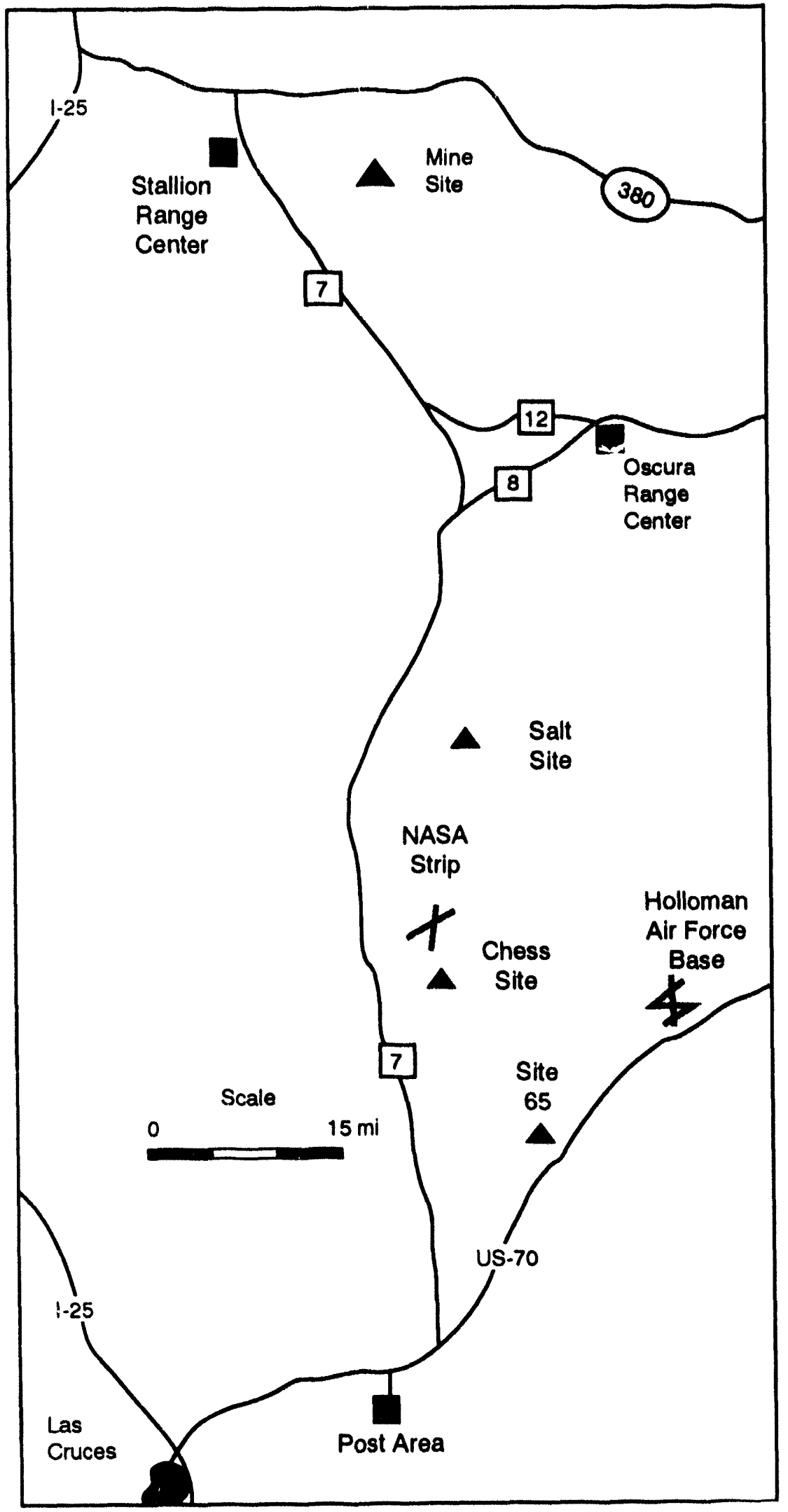

Figure 1. Generalized location of Site 65, Chess, Salt, and Mine Sites on White Sands Missile Range in southern New Mexico. 


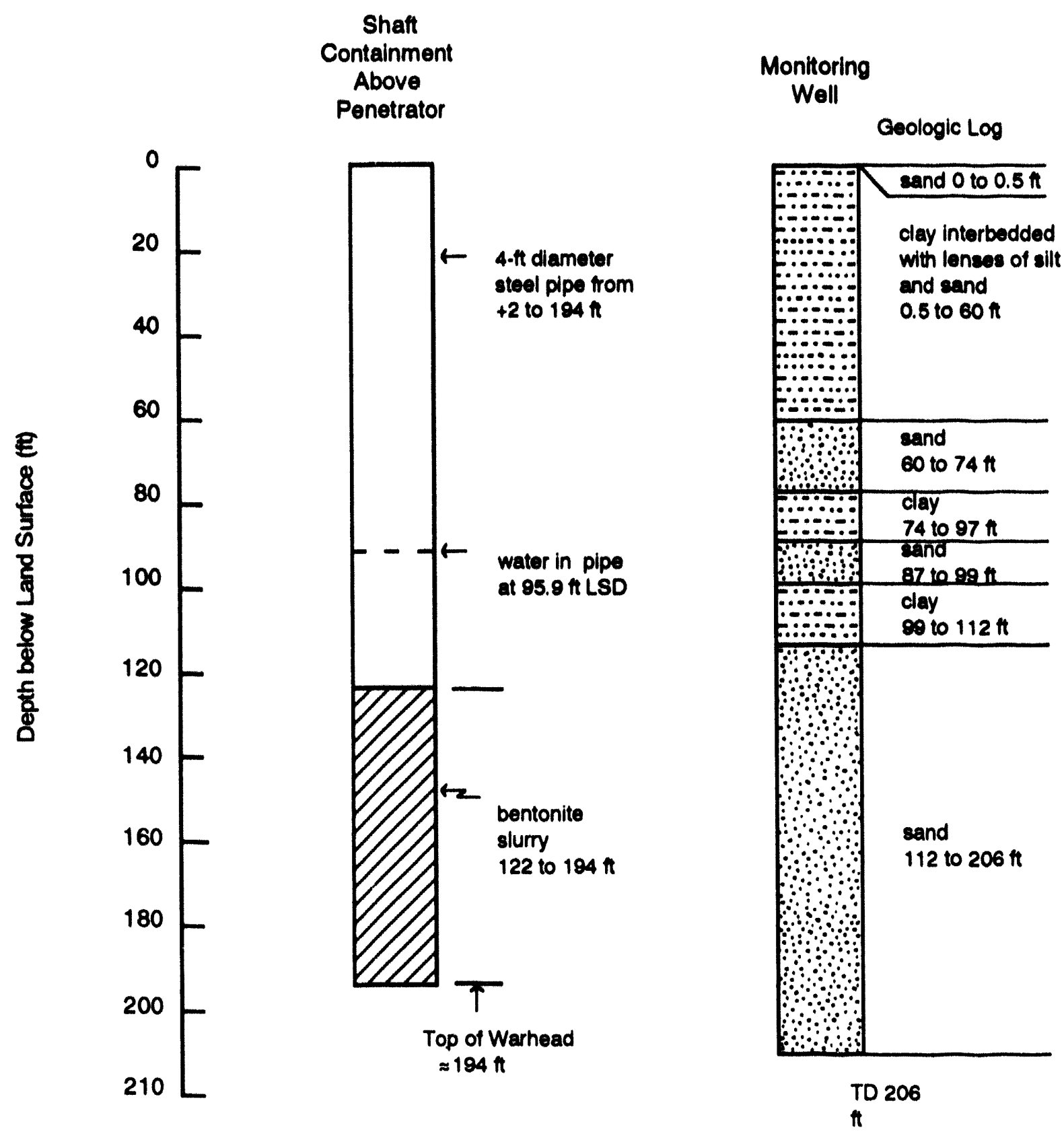

Figure 2. Shaft containment above warhead compared to Geologic Log of monitoring well (well located $15 \mathrm{ft}$ southeast of shaft). 


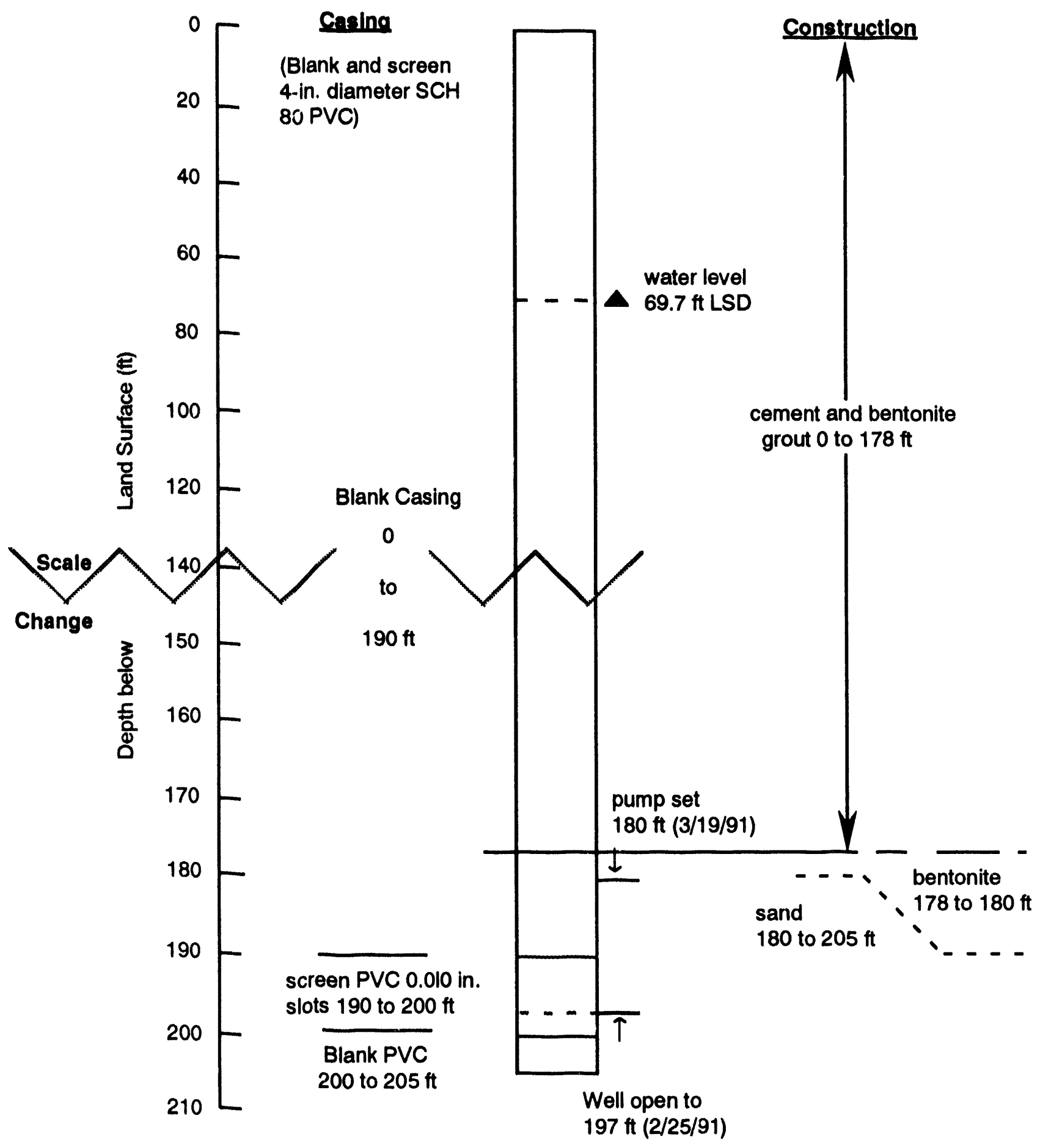

Figure 3. Well construction, water level (2/25/91), and pump setting on monitoring well Site 65. 


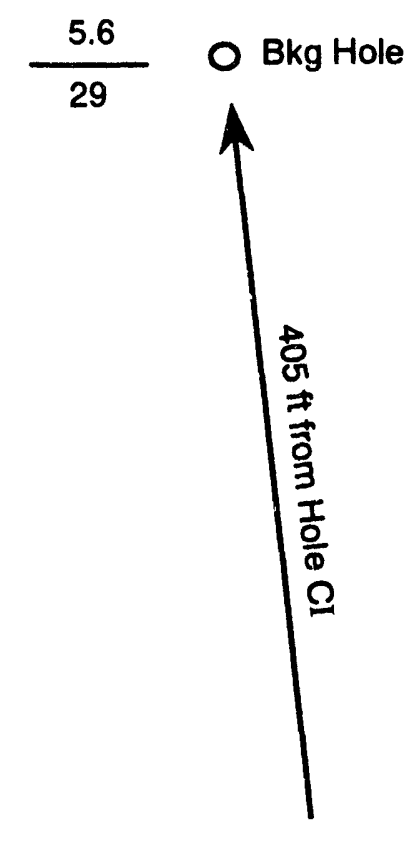

$$
\frac{6.2}{9} \circ \mathrm{N}
$$$$
\frac{\mathrm{Dry}}{19} \ominus_{\mathrm{W}} \frac{4.9}{23} \circ^{\mathrm{CI}} \frac{7}{18} \bullet^{\mathrm{E}}
$$

\begin{tabular}{|ll|}
\hline \multicolumn{1}{|c|}{ Explanation } \\
\hline 0 & $\frac{\text { water level }(\mathrm{ft})}{\text { depth drilled(ft) }}$ \\
0 & hole plugged \\
0 & cased or open hole \\
\hline
\end{tabular}

$$
\frac{5.4}{28} \circ^{S}
$$

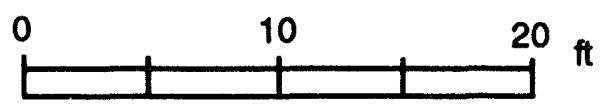

Figure 4. Location of test holes at Chess Site. 

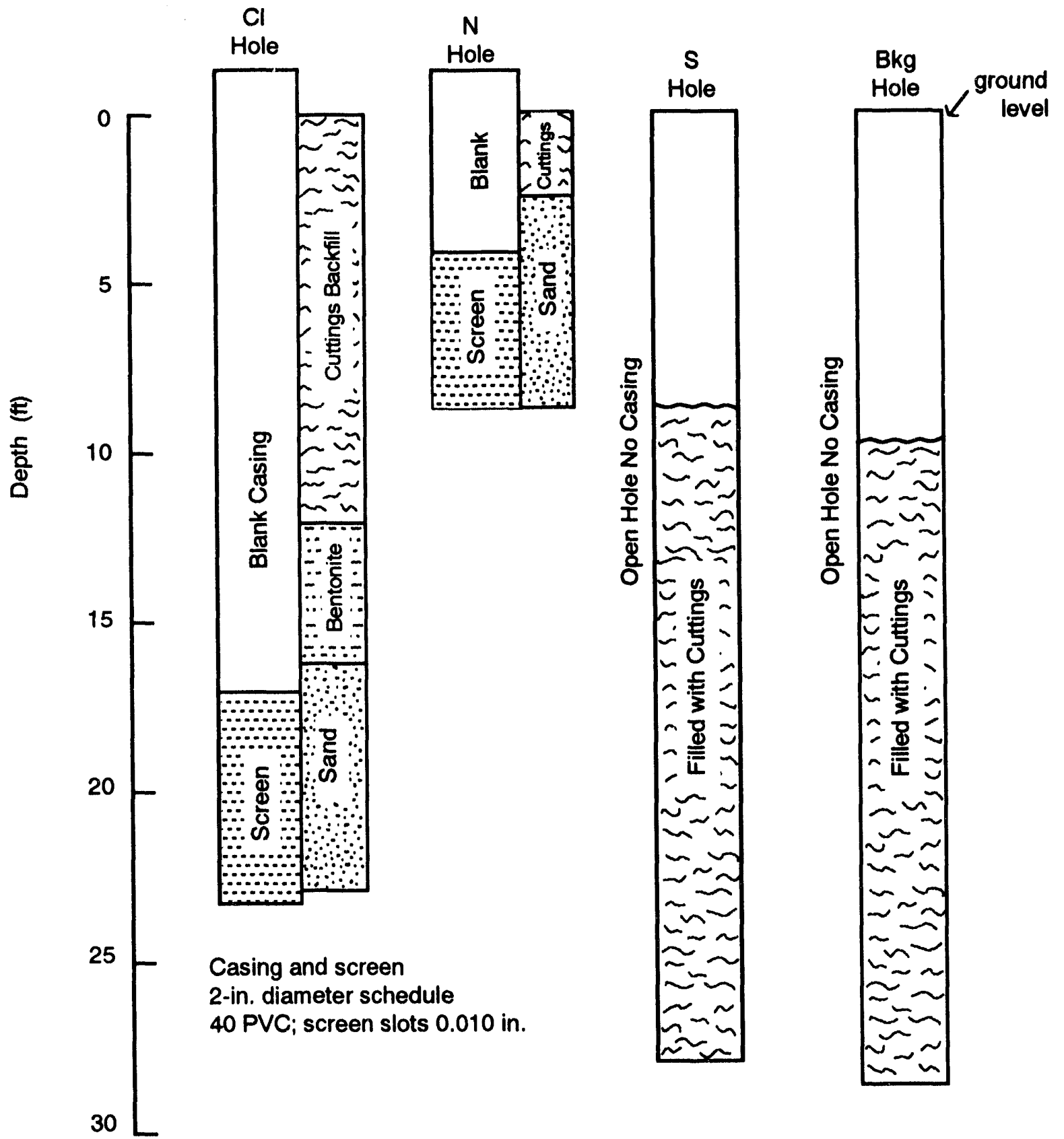

Figure 5. Casing schedule and open holes sampled at Chess Site. 


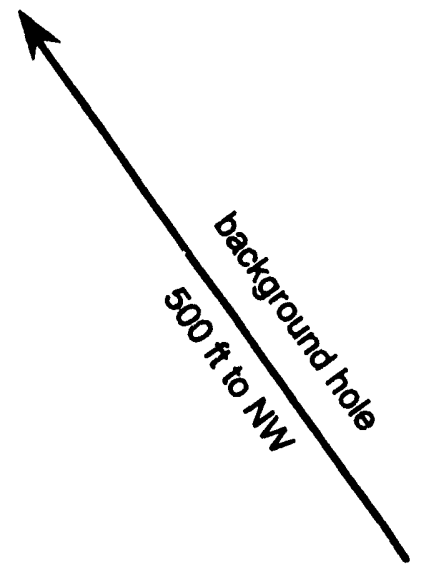

\section{$290_{\text {sW }}$}

\section{SE}

\section{depth (ft) $O$ Test Hole}

Note: All holes dry,

plugged, and abandoned

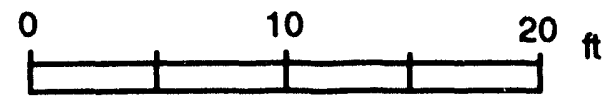

Figure 6. Location of test holes at Salt Site. 


$\leftarrow \frac{\text { background hole }}{1,000 \mathrm{ft} \text { to west }}$

39 O w<smiles>CO[13CH3]</smiles>

- Impact point

49 O

depth (ft) $O$ Test Hole

Note: All holes dry,

plugged, and abandoned

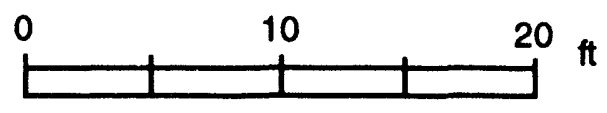

Figure 7. Location of test holes at Mine Site. 


\section{APPENDIX A}

Geologic Logs of Core Holes 
6

$$
6-10-91
$$

Setup on chess $I 473464$ This $x-4$ is a wsmR ard ${ }^{y} 35984$ Irst hole is at stefe point

Septh sescription.

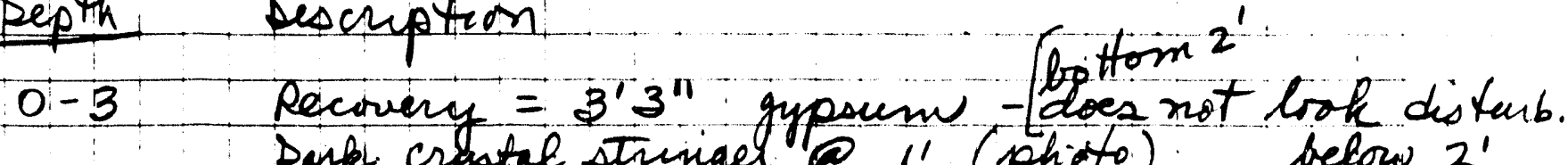
Dank cratal stringel $21^{\prime}$ (photo) below $2^{\prime}$

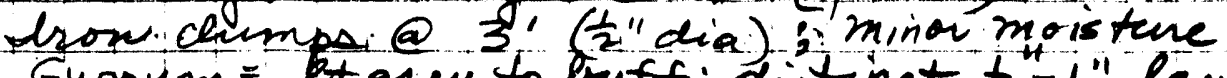
Gyparm = bt ge to touff; distinct $\frac{1}{2}-1$ layers.

3-8 Recavery $=4^{\prime} 5^{\prime \prime}$ ipome compaction due to coring gypoum dark pey, moist to $3^{\prime} 6^{\prime \prime}$, photos If lot $=$ et grey to baff color wh tape in yelfowish prey lyere 6' (is thes sulphai) meane 8-13 Apparent water contact at 8ft (photos-toon) Reconery $=2^{\prime} 5^{\prime \prime}$ care blt gypsum vey dense -coubarrel compacted gyoum, lark grey; top 1 "s" is saturated botom " is not saturated photas $\mathrm{H}_{2} \mathrm{~S}$ ade veny distinct in upper paturated core microcryptacline gypseum Thru-out $(0-13)$ w/ many "s" and smaller diatinot gypsem crystile (looph like jibreous glast charda)

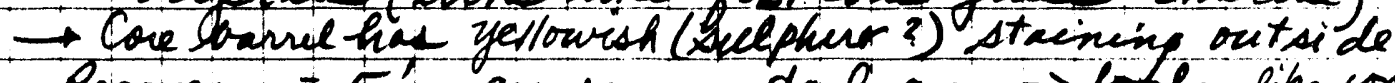

$13-18$ Recovery $=5^{1}$ gypsum - dark grey $\Rightarrow$ lobhe like concrete Core looba wet in phato lant wated is from 8-13' making a wet rine around dryer gypoum inside No $H_{2}$ S adou - water is perched at \&-13! Rine semoved betore sampling - corf is relatively densei $1 / 8$ "gypsum enjstal apporent

18-23 Recoury $=5^{\prime}$ basrel well ex panded ' chilled haid

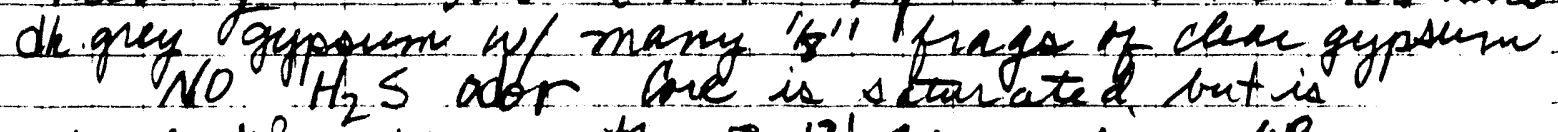
probably flom the $8-13^{\prime}$ zone simes we strpped $15 \mathrm{~min}$ tor lunch before setting

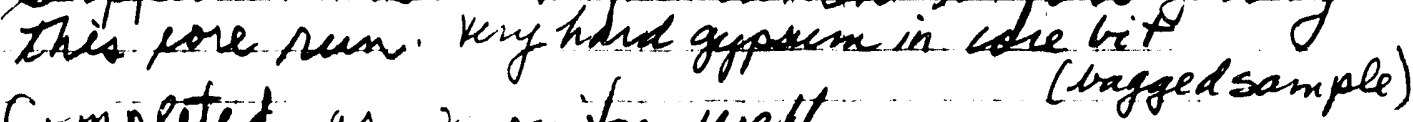
Crmpeted as ri. onitor well.

27 


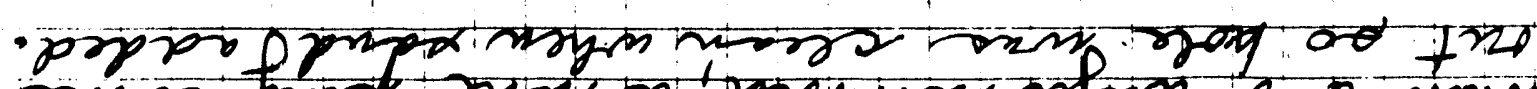

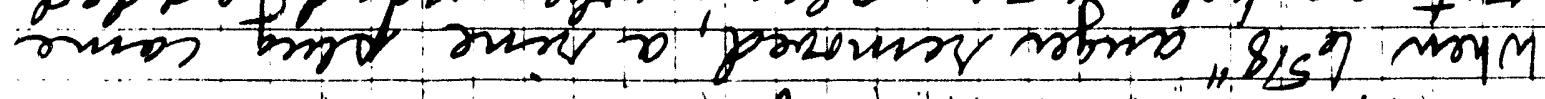

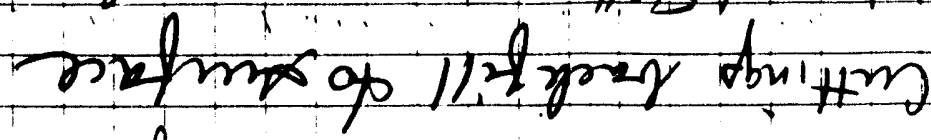

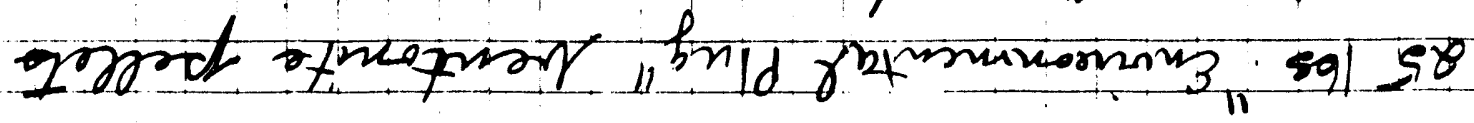

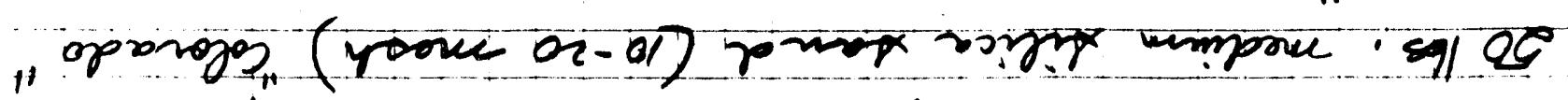

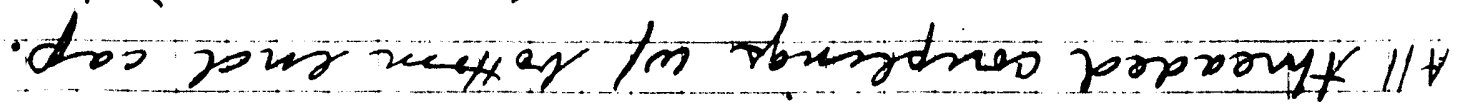

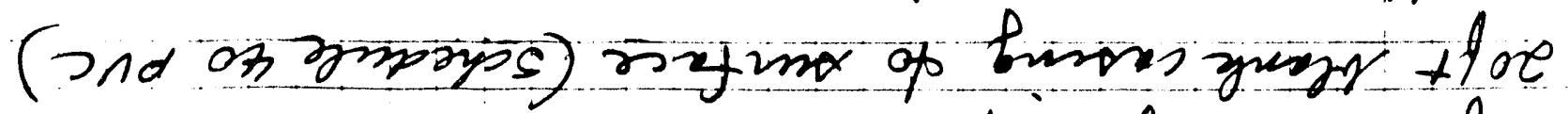

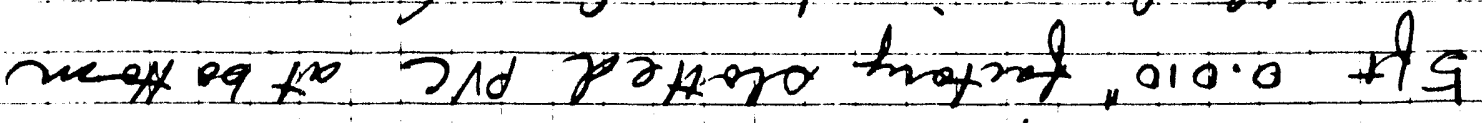

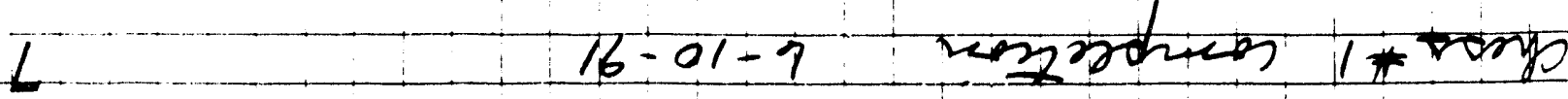


8 6-10-9): Chesd-west tole =10ft. Weot of Chess $* 1$

Depth sesciption. $0-4 \quad$ Recovery $=4 f$ oin. Hard pan $2 b^{\prime \prime}$ helow surface White to buff brown gypsum w/miciocrystalline matrix and $v$, many joge of clean gypsem

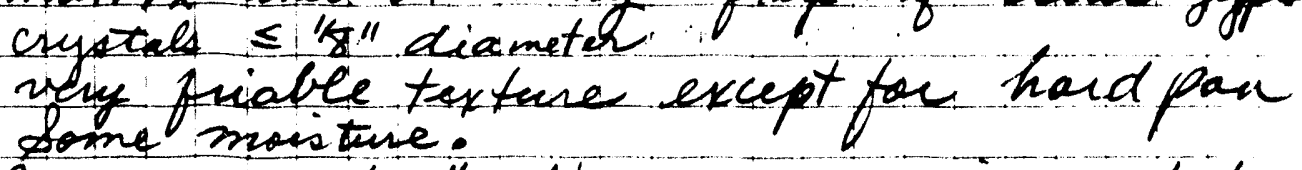
4-9 Recorreng =2 fto". Aard gypscam in cove bit White to buff krown micro eupt, gypoum w/ many prags of cleav "ridia gypsem a dus to yellowish brown gappen hat sime moisture. The zft of core is afparenty from 4-6ft below quound and b-9ft. is taturated Ance care ivit was peugged.

$9-14 \quad$ Recoving $=26+91$

Dakl grey gypsum w/ sulphus odov on wattom 2 t. move moistare Yaan aboue but mat $100 \%$ satarated. Core hit = hard gypoum but core tarrel gyp. is friare.

tuspect: $6-10 \mathrm{ft}=$ satirated jone based on drilling tounds

Augen is making "mud-ball" like it is in or near water bat there is no watec'in hole.

tispect: Disturded area broke thru shallow hard pow and allowed. (or create d) porched zone.

14-19 Anges is notw yeiding ta turated ciettings Recovery =1ftlien.

Bandede white and daik gley gypsem Low moistare - standing water is leakage fum avove. Some Hz ador but not as strong ax abre.

29 
Abandoned

9

$|6-10+9|$

Chess-Noith $\simeq$ loft North of Chess $\#$

Depth Description

$$
0-4 \quad \text { Recovery }=4 \mathrm{ft} / .
$$

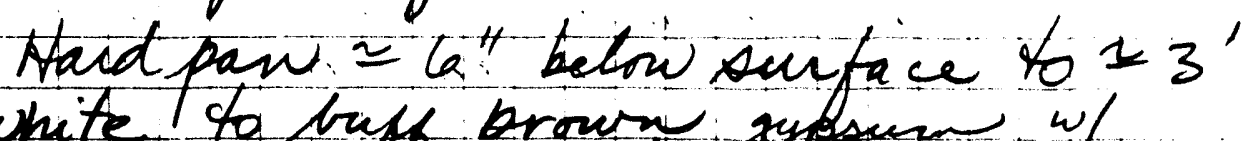
white to bute brown ry pain w/ minocustallue matrix and frogs 8 clear

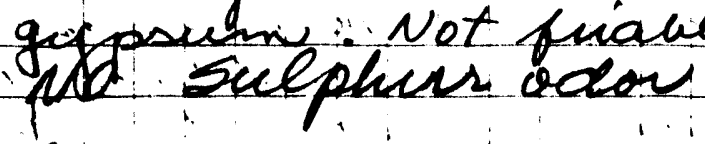

$$
4-9
$$$$
\text { Recovery }=26 \text { t ot }
$$

Bottom $14 t=$ dank grey gypsum

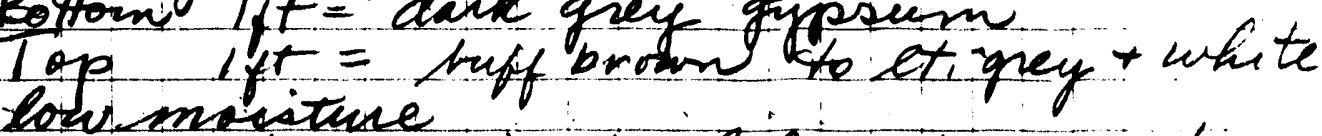

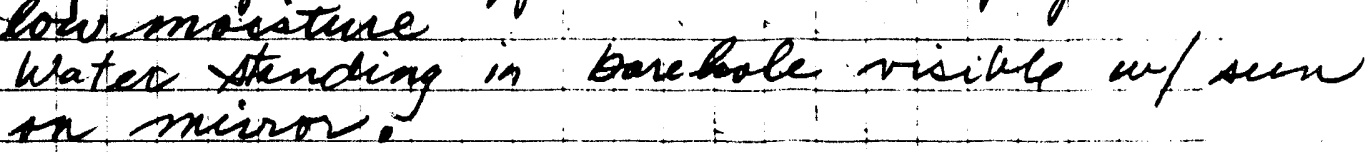

Competed as monitor well.

5 ft 0.019 in factory sited handicap 5 ff casing at top - threaded joint

so lbs. medium lasting send - $\approx$ it above slots $\frac{1}{2}$ bag bentonite pellets + cutting at tap.

$6-11-96$

GPS Reading biz

LAT $32^{\circ}$ कर $50.4 \quad 30$ west of ms L 3960

30 


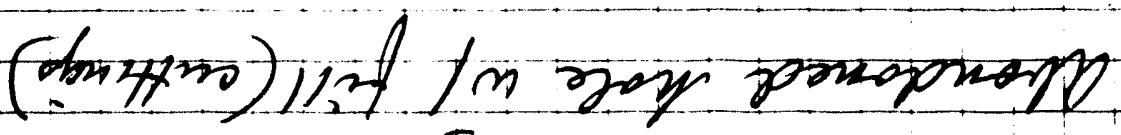

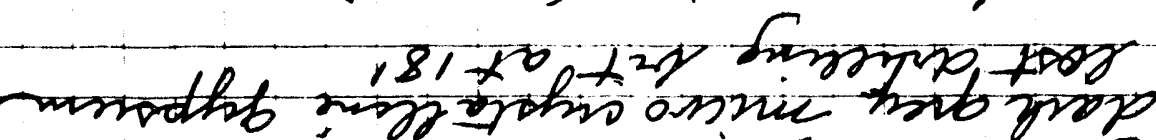

nopos $5^{2} H$ Pryp

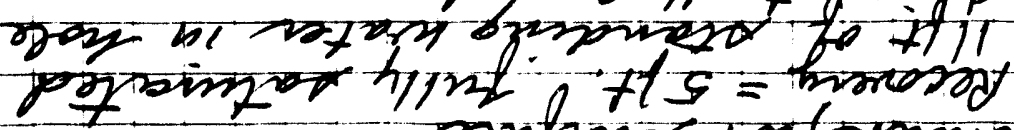

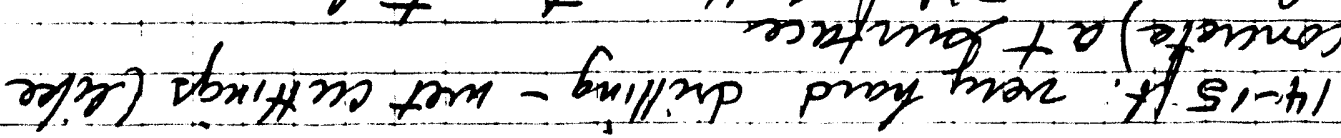

$31+h$

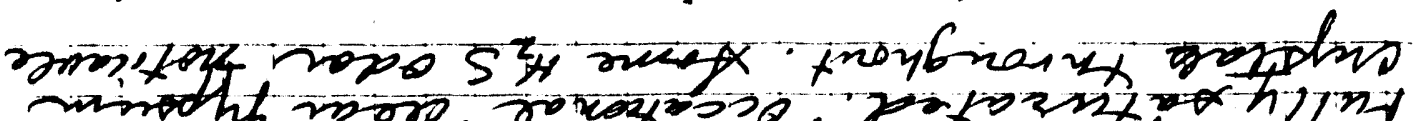

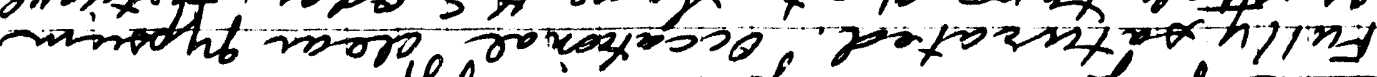

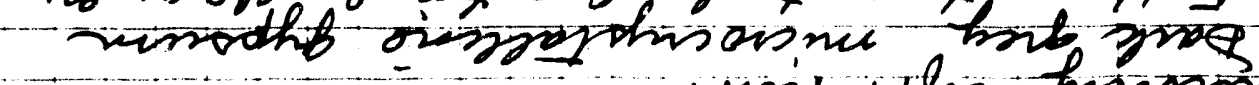

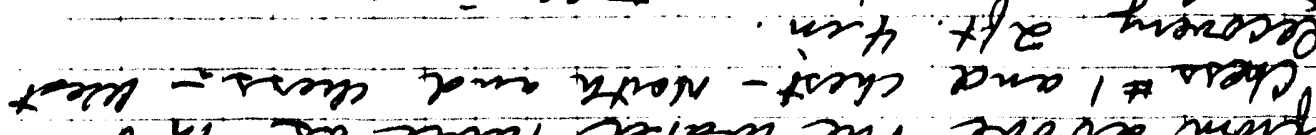

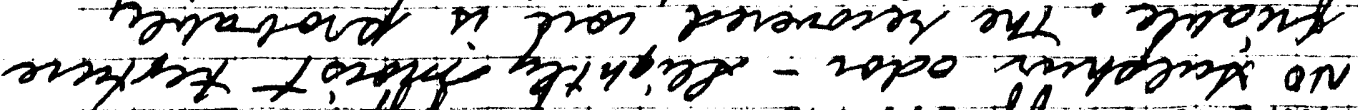

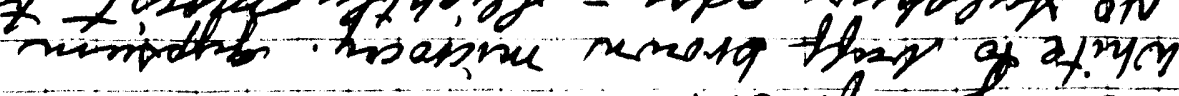

$$
\text { in } 8+21=\text { horeog } \quad 6-h
$$

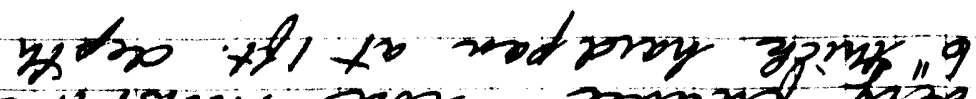

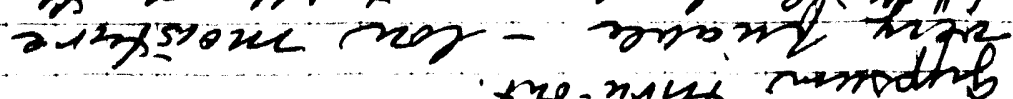

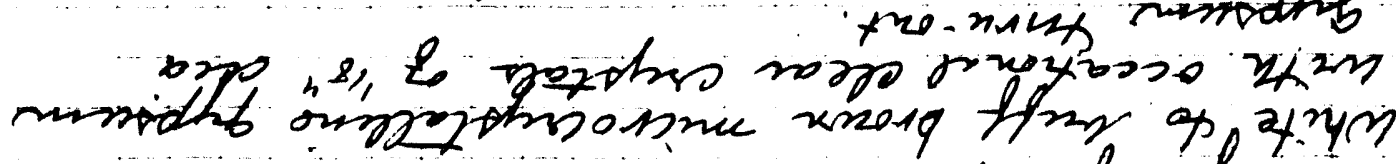

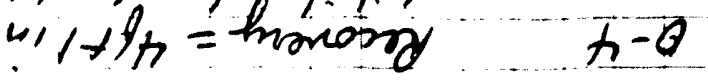

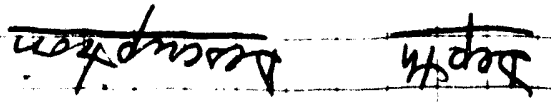

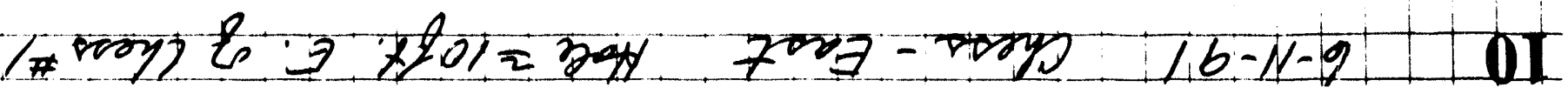




\section{$\tau \varepsilon$}

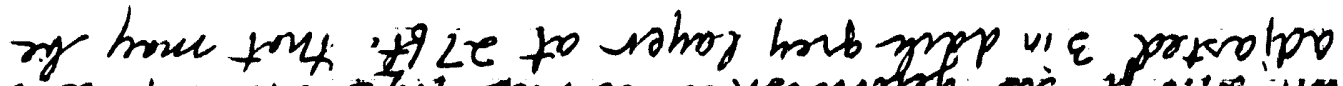

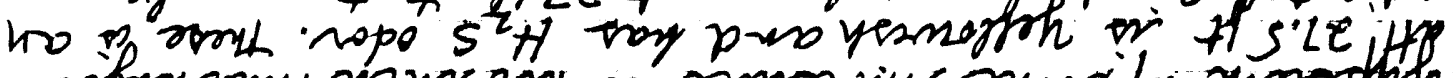

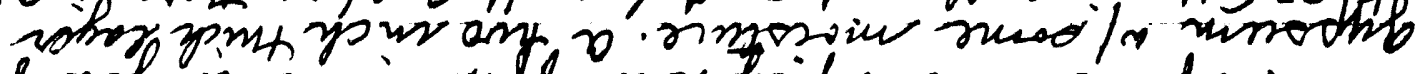

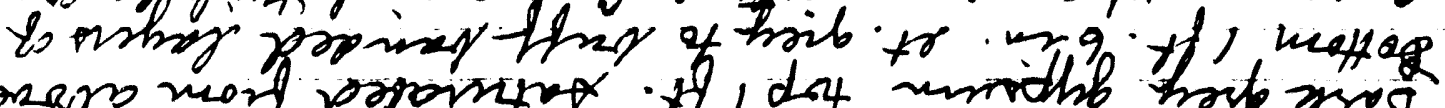

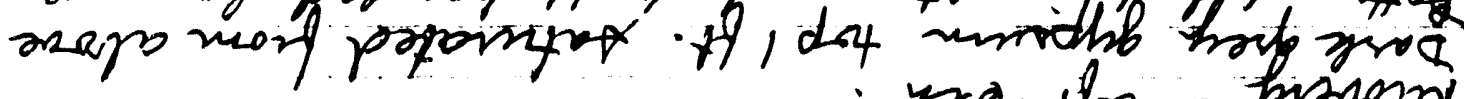

$$
\text { wo yle }=\text { insosy } 8 \tau-\varepsilon \varepsilon
$$

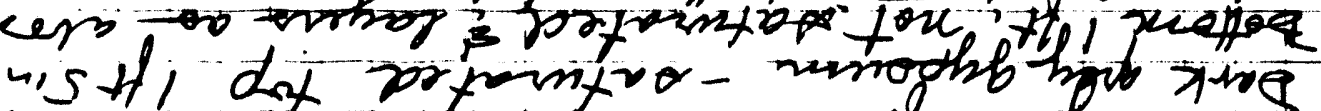

$$
\text { ws HC = manory }
$$

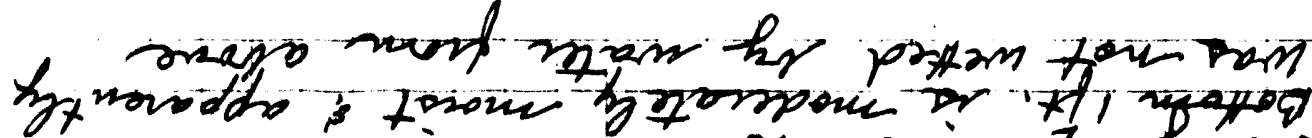

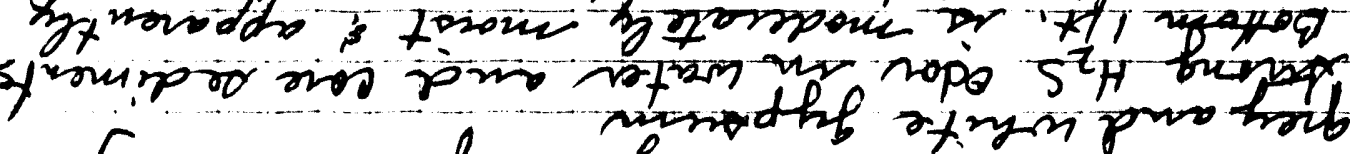

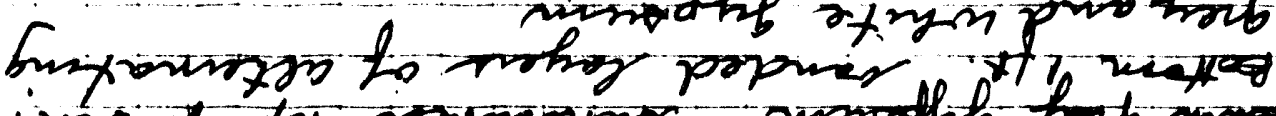

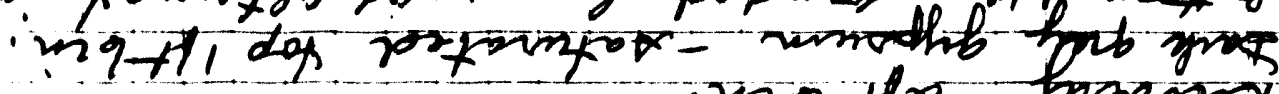

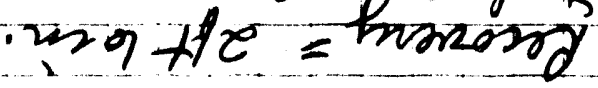

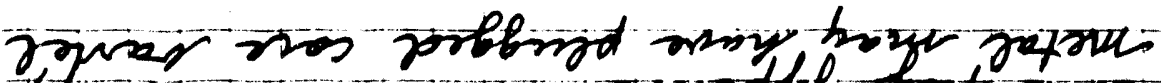

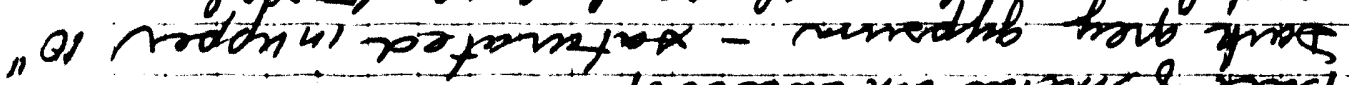

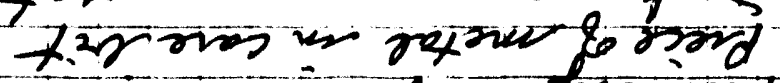

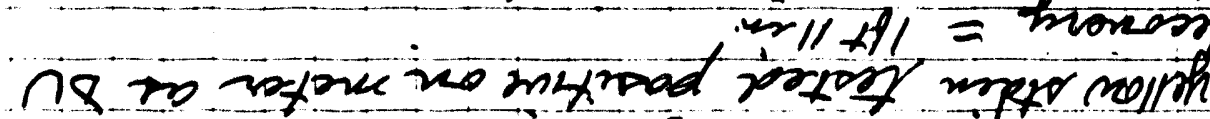

$$
\text { ropo } S_{1}^{2} \mathrm{H} \text { io mijons aN }
$$

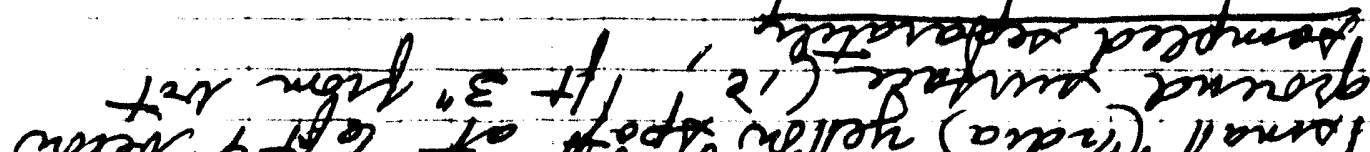

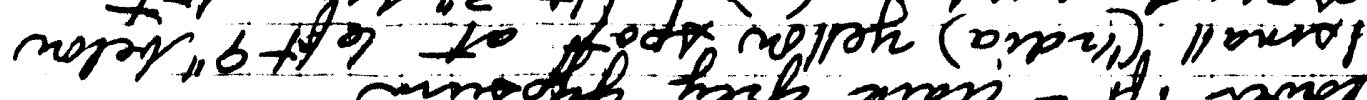

$$
\begin{aligned}
& \text { s zoos }=\text { A', pand }
\end{aligned}
$$

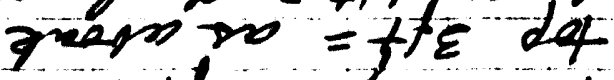

$$
\begin{aligned}
& \text { In } 0 f_{t}=\text { Inomess } \&-\varepsilon
\end{aligned}
$$

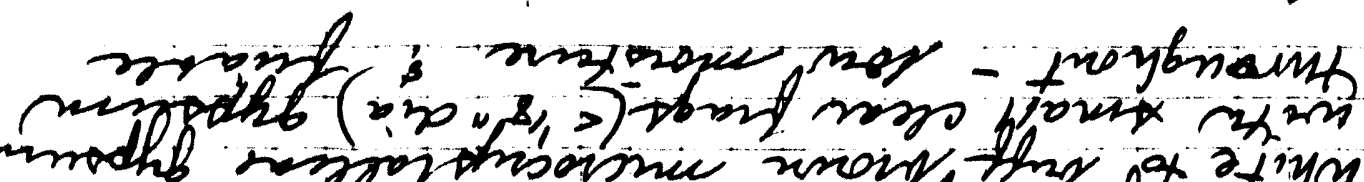

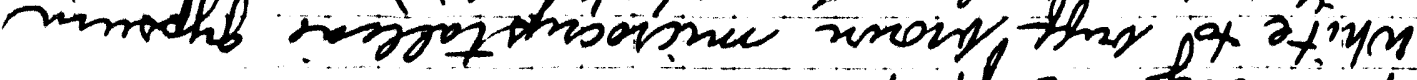

$$
\begin{aligned}
& 116 \text { if } e=\text { haraso } \varepsilon-0 \\
& \text { प्यक्यक्य } \\
& 3 x^{\operatorname{rog}}-\operatorname{poys} y 6-11-1
\end{aligned}
$$

$$
\begin{aligned}
& \text { - pol tetz somp } \\
& \text { OOए itorm इन्यु० } \\
& \text { at vtwas डsक्रण }
\end{aligned}
$$


12 b-11-9l Okess-South con't

Septh Disifition

23-28con't an old weathered hocizon.

the gypserm teens to weatine to dack grey if there cs any watee cinta ot.

- openderibeol herle bayged ondop lesot fillad, chess. Bky

$$
\approx 135 \text { Y.d North } \approx 355^{\circ}
$$

Lat - $320^{\circ} 52^{\prime} 5^{\circ} \quad 56.0^{\prime}$ w $3959^{\prime}$

Depth $\frac{\text { Descioption }}{\text { Pecon }}$

$0-4 \quad$ Rhite $=4$ it 3 in

White oo buff brow micsocrystalline gypsem with many small cleav gyfum cryates inru-ont. Sry and friaule. No distinct hand pan laye wo HS odor move comse than below (grain sige $=20$ mesh)

4-9 Recony $=21+5$ in

As above Bottom 6" is banded white and black gypsum, Nomoisture oc 12 S wh is placavly $6-10$.t. as in atner holes

$9-14 \quad$ Recovery $=3$ ft 3 in

Duch orey zypum - mare moistire but

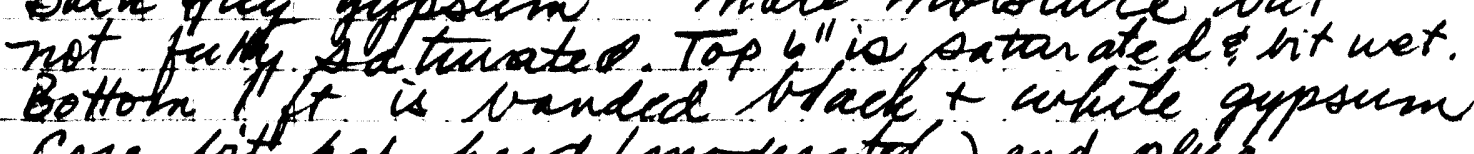
Care it hat hard (moderately) end pling.

$14-19-$ Recovery $=$ aft on

Domk grey gypsum - Anturated at top b" moist las 11.5 ft... H2S odou (errenobic) Dack grey color $+H_{2} S \Rightarrow$ probavly bacterial action in presenceof misture $\rightarrow \mathrm{H}_{2} \mathrm{~S}$

obsewation from wsmR personnel $\Rightarrow$ gily-tug noumally trane ponded woter here (Chess site) fiom toumnew 
Chess Background cont 6\%11-97

13

Septh Description

Wateclevel $=8$ gt below land surface measured iy wet mask on core boung

19-24 Recovery $=3 \mathrm{ft} 8 \mathrm{in}$.

Dark qpey gypum - moist where not contaminated by infiltinforion from above

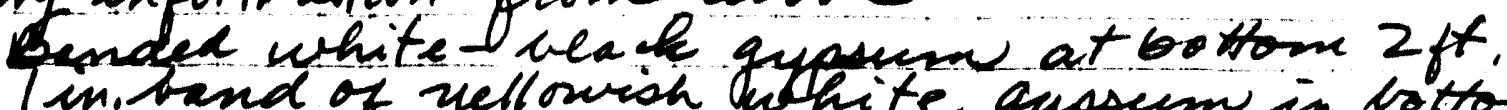
6 in. scight $H_{2} s$ odou

$24-29$ Recorvey $=2$ toin.

White to mostey bufferown microcruftalline gupsum at bom pt. pading into leaked ghey gypsum in upper fft kery hand gypsem In courit and molevate fribue in cou binel seight $H_{2}$ s odoc. Lots of water in upper 3 ft of banel.

Atondined hole - no complaton.

Filled hole with cuttings

34 
$14 \quad 6: 12-91$ thlt Bcilground

Depta $\frac{\text { Secreption }}{0-4}=3$ ft $10 \mathrm{in}$.

It. Brow wil fine pain, diy

4-9. Recovery = 1 ft 9 in.

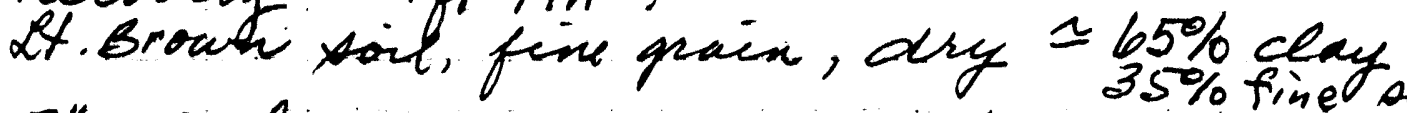

$3^{4}$ calache layer at bottom; hit pleigged extended cole passel $2 \mathrm{in}$.

9-13 Recowy =5jt cue Barrel tet@60" At. todich brown, clay sich soil (?) manctine grain cryetak of mica, guastz, halits, Ut this a lacustrine dipesit (?)

$13-18 \quad$ lecovery $=5$ tt.

Oark redaish brown say (oi kalite) mica, qta and calcite soryt al frags (micro)

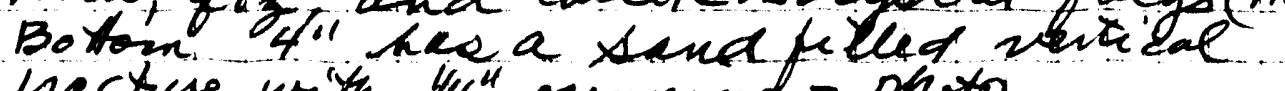
practure with "4" openning-photo

$18-23$

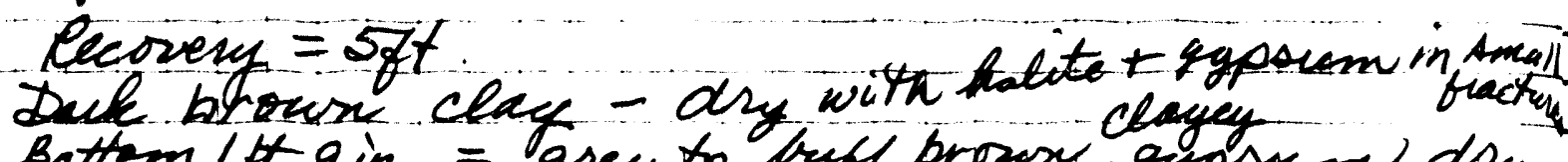

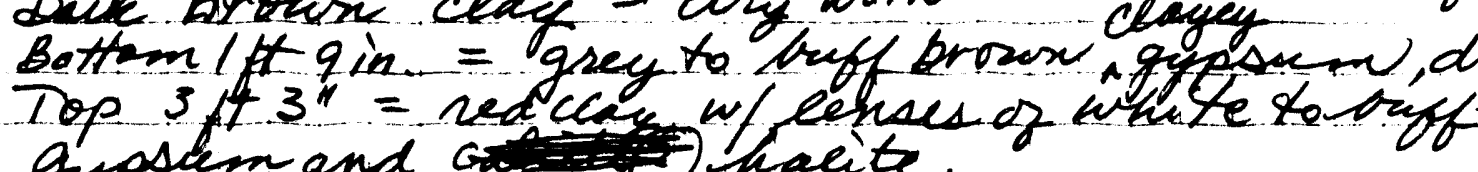
gypsam and onate.

$23-28$

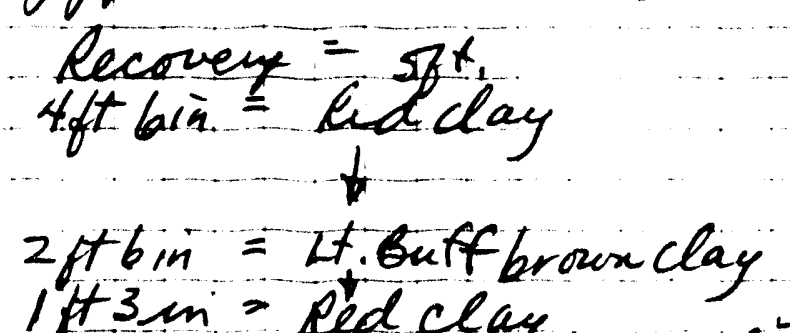

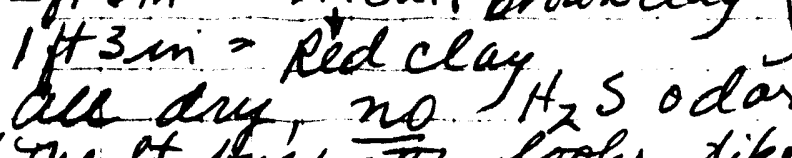

(The et Any o looks tike it has limonte

Istaining and ison stiming

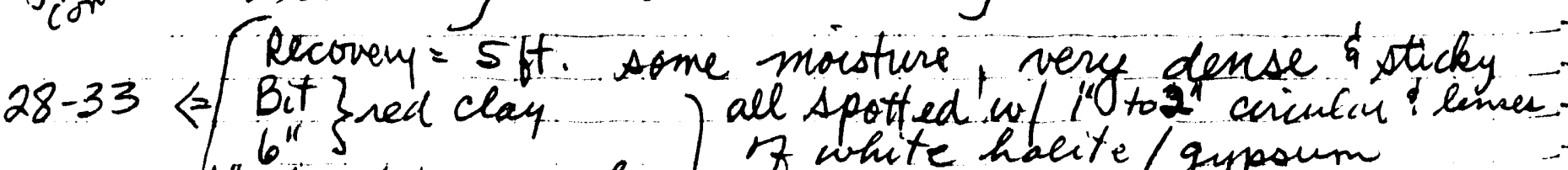

$6^{\prime \prime}-^{\prime \prime}$ l' et.brow clay of white hbeite / gypoum

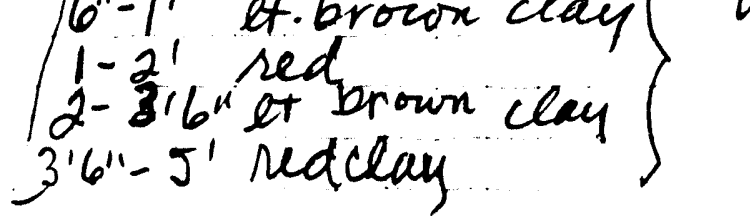

Can not taste suet

Filled in hale

35 
15

Lat 33,08 of.5 +3940

12.20 melors (map)

to-12-91 stalt SE

Depth $\frac{\text { Descrition }}{\text { Retover }}$

Recovery $=3$ flage 0 in

friabe clayey sand poil - loohs distuibed friable, dry; Several chenks of gypsum (?) $\leq 1 / 2^{\prime \prime d i a ~}$

4-9 Recovery $=5.17$.

Lt. Brown trayey soid with lacustrian deposits Occational l/2 dia rock fiege of gypum

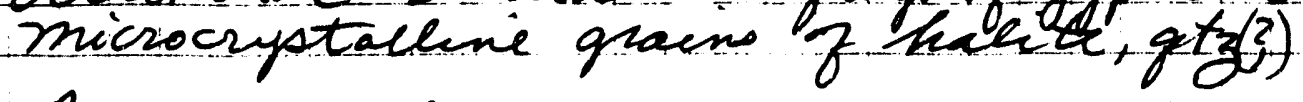

9-14 Recovery $=51 t$

Sense dark brown clay with micsocuptalline hacite strengers ( "k" $^{\prime \prime)}$; love to mod mostare and stcile (suchs to core bavel) $(14-126 t)$ $12-9 \mathrm{ft}=$ sandy clay not as dense

$14-19$ Recovery $=5$ ft. many isrigueas mall clanstes of white cystalim gypoum mruout; wery dense - Making baces lecovery $=5 \mathrm{gt}$.

White to triff brown clay, dry, firanle One dark, dense red cedy layer e 2 . Stit is quite different than slet Background.

filled in hole

$6-33^{a 1} / 5$ hiat 330 o $7^{\prime} 552^{\prime \prime} \quad 4835^{\prime \prime}$ ELJ $\log 106^{\circ} 21^{\prime} 46,3 \approx 30$ south

36 
$16 \quad b-12-9 T \quad$ Salt sw

Depth Description

0-4 Recovery $=3 f 0$ in

Bottom- UP: $P-1$ - 5 in $\Rightarrow$ dense red clay $w /$

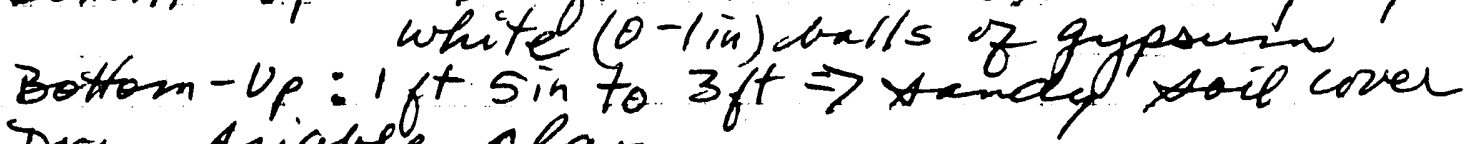

Dry, friable clay

4-9 Recovery - sit

Bait red dense clay occatorial fine Stringers of grainy band t gypsum oft to $7 \mathrm{ft}$. filled with stand + gypsum

$6-13-91$

9-14 Recovery $=58 t$

Dork red dense clay less moisture than yestarday-may hame bred out over night

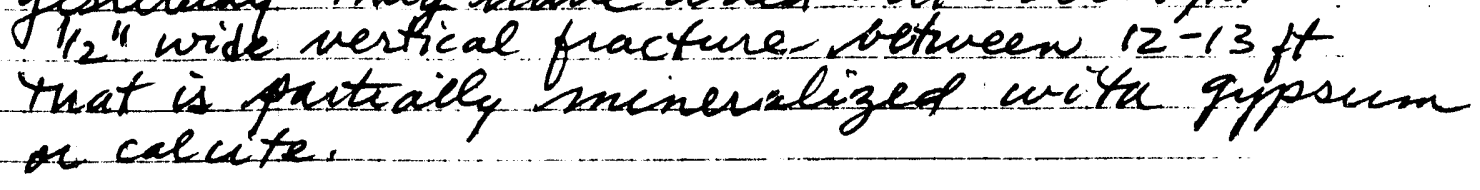

14-19 Recovery $=5 f t$

Dark ked dense clay, moderate moisture marked w/ white micuenystalene gypenn Approx. $15 \%$ vol content 7518 "tia clew Gypsum i esyotal turu-hit. Some caring induced fractures at lower lift.

19-24 Recovery = aft Distinct color change @19' White be be f brown fine grain gypsum with clay g NoTE thin contact and compare was very distinct.

24-29 Recovery = St White to buff brown fog. gypsum to 25.5 t

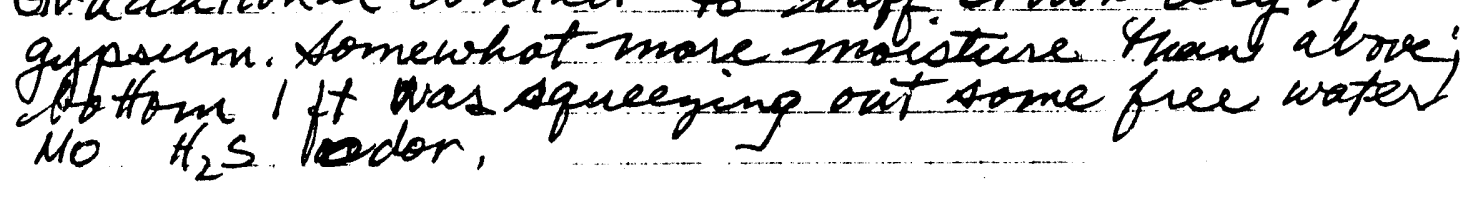
Filled in hole.

37 


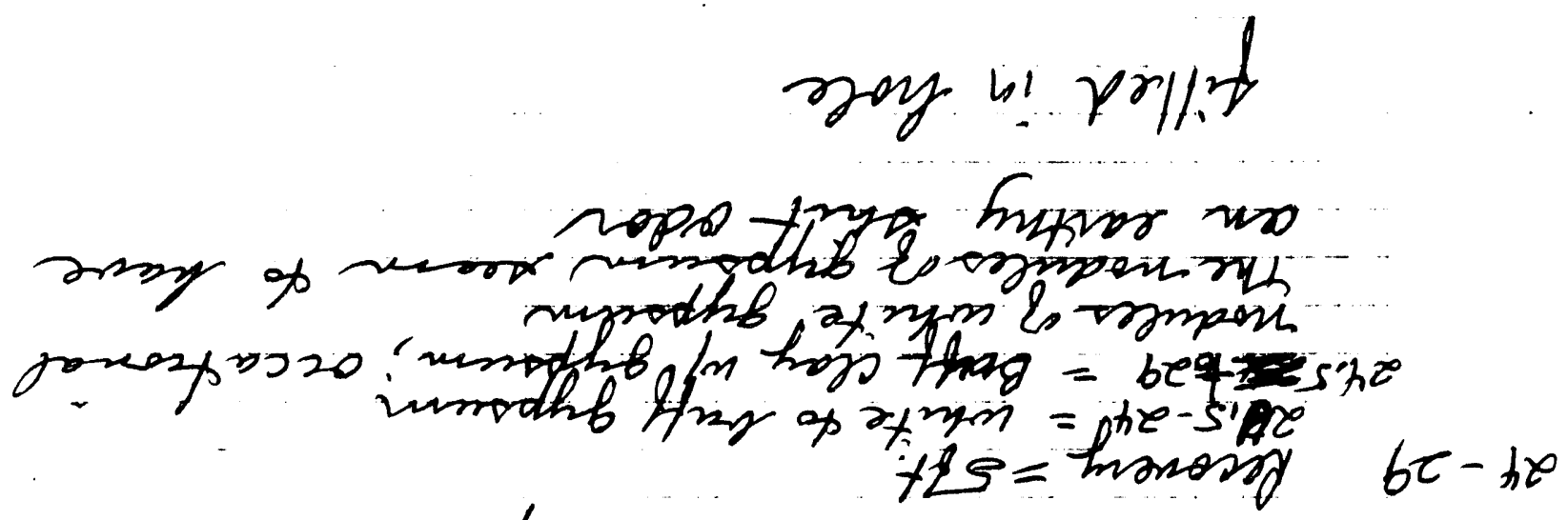
higgo nowno mop $=$ on- bl

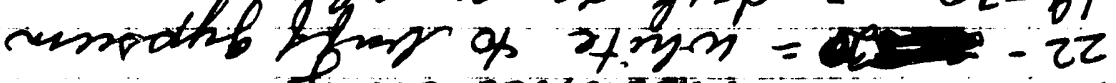

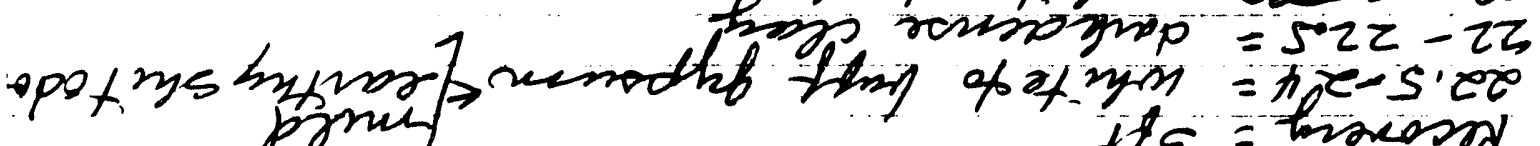

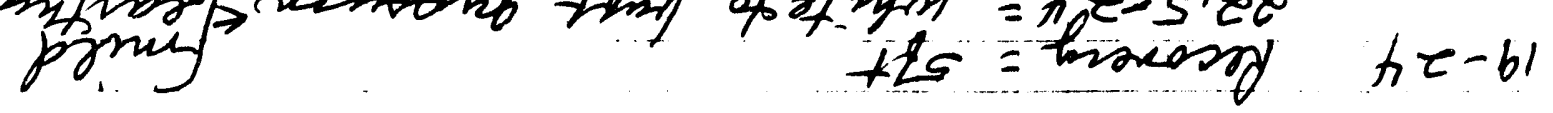

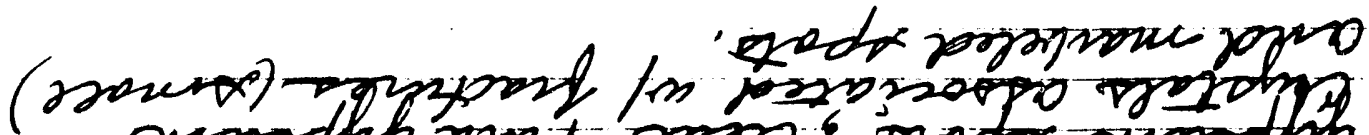

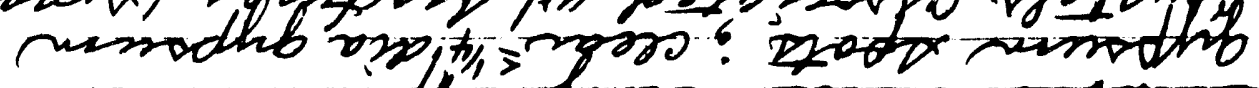

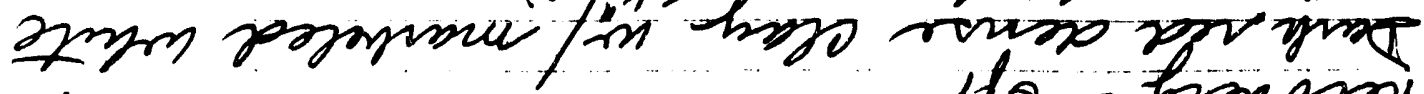

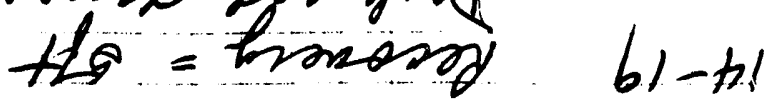

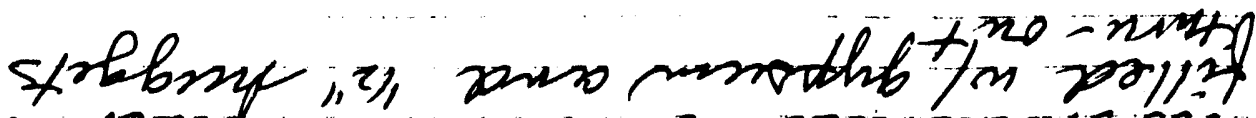

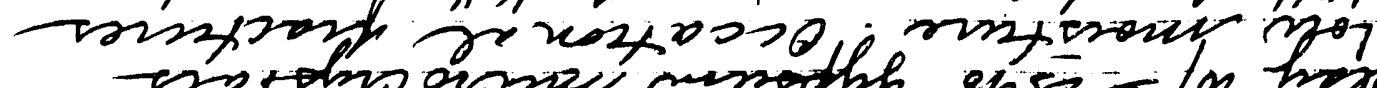

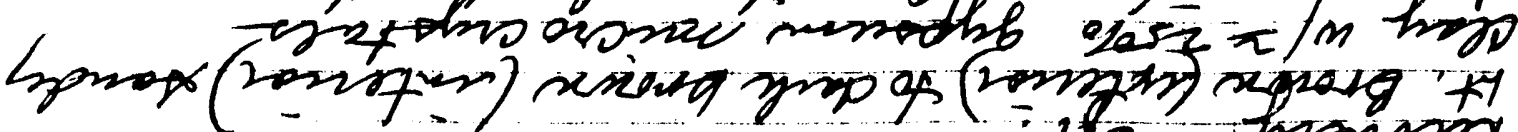

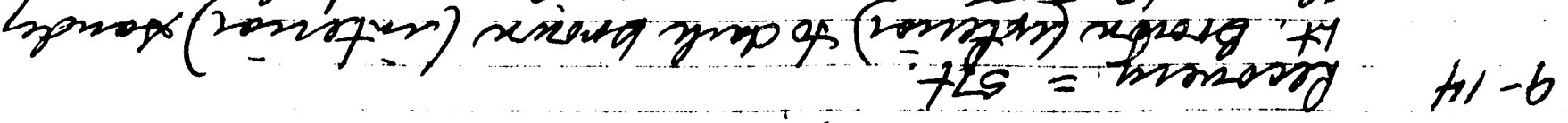

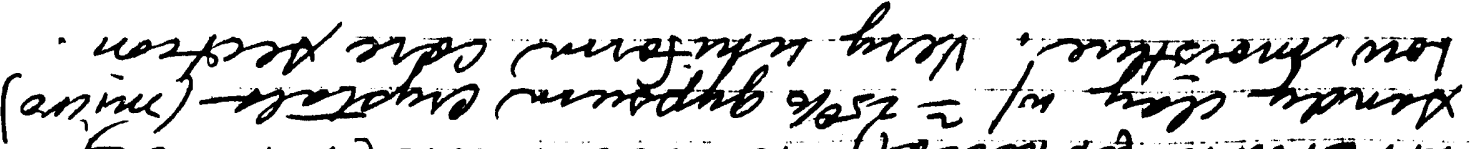

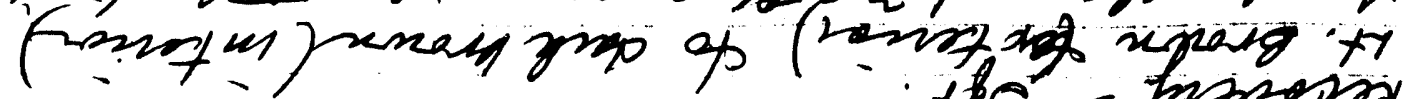
tog - masosio cbarf rumpthb

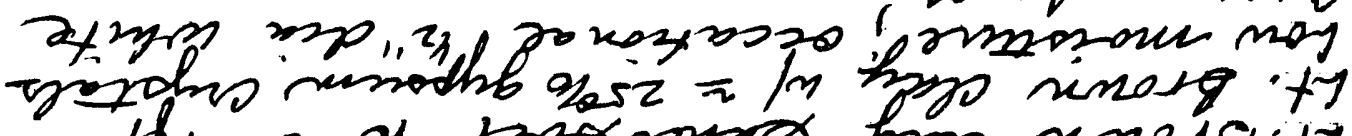

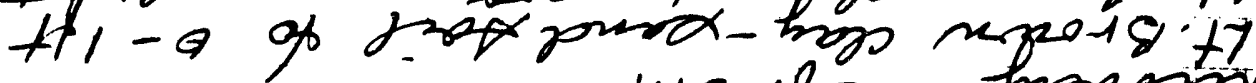

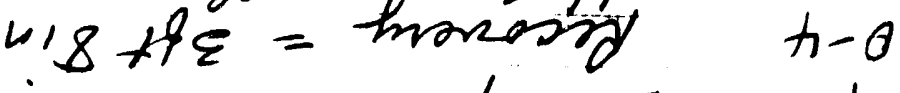

$$
\begin{aligned}
& \text { unistintrot hotor } \\
& 1+12 \pi-r b-\varepsilon 1-9
\end{aligned}
$$




$$
\text { 6-13-9/ Siet NW }
$$

Septa Descriftion

19

$$
0-4
$$

Recovery $=3$ fto in

$0-1,5 f^{t}=$ et. brown clay - And soil $15-4$ = Lt. buft gypoum-clay botion 2 in = dath sed ceay w/I" fracture

4-9 Recovery $=$ oft.

Lt. Brbwr (extecior) to dach brown(interior) tandy Ceay $w /$ I $250 \%$ gypsum micro cryptals the moisture. Very unitom frow above extends 1 into top of this core; fracture 9-14 Recorats.

Lt. Broun (efteion) to dack brown (intevis tandy clay w/. $25 \%$ gypsum microcriptals Low moisture. Very unitorm

$14-19$

$$
\text { Recovery }=\text { sft }
$$

$14-14.86 \mathrm{f}$ = brown Aendy clay as aboue 14.8-19 = dailired dense stidey clay w/

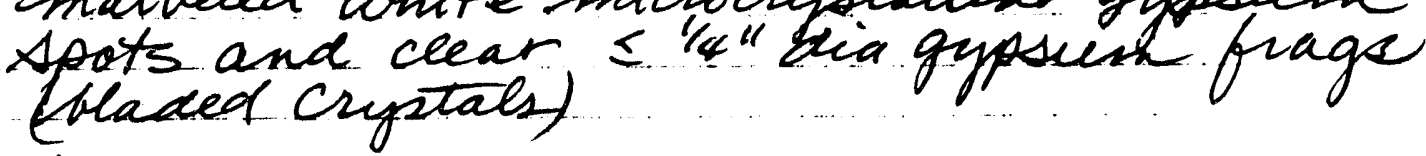

$19-24$

Recovein $=$ sf

top 2 in = dense red clay of above

$19.2-21.2=$ white to buft gypsum
$21.2=21.9$ a dense rest doth clact

$21.9-24=$ white to buff gupsum

$24-29$ Recovin $=574$.

$21.5-24=$ white to brift gypsum

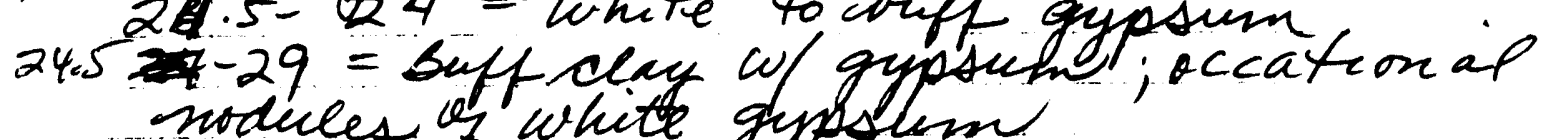
nodules of white grpstem

filted w/ atteng

39 
20 b-13-91 Halt NE

Depth Siseription.

0-4 Recovery $=3.5 \mathrm{ft}$

5.1 .5 lf brown sundy soil

1.5-4 lt. buff gypsum t chay

4-9 Recovery $=$ sft.

et. broutn atterior to dark brown interiar.

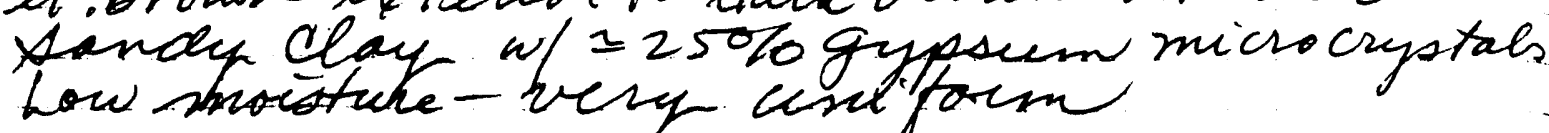

$9-14$ Recoviry = sft

4t urown exterior to dark boun intevio tandy fay wi $25 \%$ gupsum microcuptals modiatelf ebw nodstie-veryuniform

14-19 lecovery $=57 f$.

$14-15=$ as avove ef todack brown yendy clay 15-19 = daik red cense stich clay w/

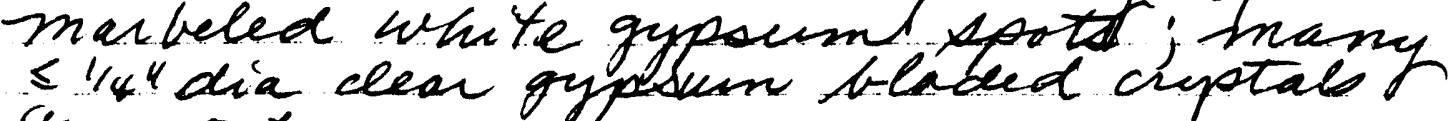
thru-oux.

$19-24$

lecovein $=$ Sft

$19-20.5=$ dale red stuclu clay as avove $20.5-24=$ white to buff gifssum with
eaithy shit oqfer

24-29 Recovery $=$ whtt

w/ cearthy snit to gupsum as above $26-29=$ baff clay $w /$ gypsim ojing tzo at coint bit dike to buldged

fieled hale w/ cuttongs

40 
$24 \quad 6-18-91$ mine site*1

Iepth Desingtion Abo Fm (?) Chech

Recovery $=24 \times 9$ in losey

Dak bfown to red tand thet w/ occa tional 1/2" prage of Ehite crystallic gypsum(?). Marry shiciocsuataleine forge

4-9 Recovery $=46+10$ in rayey

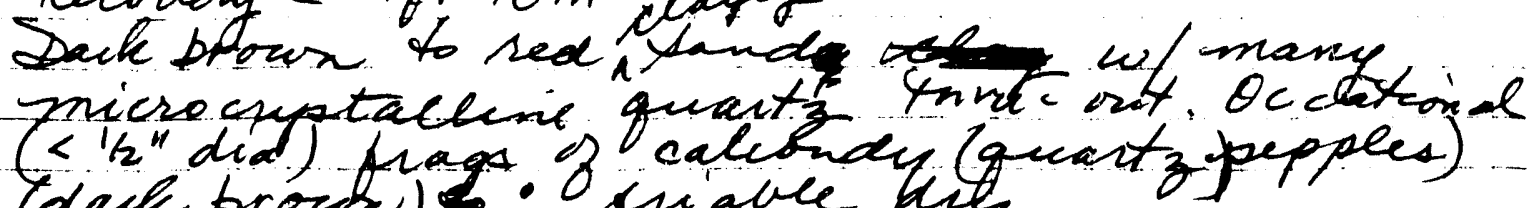

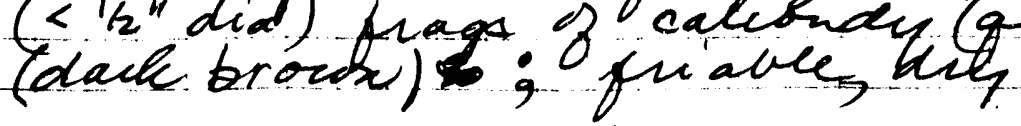

9-14 Recovery $=4$ ft 10 in

$9-10$ t. 7 in $=$ as abve (red sandy clay)

$10-117 \Rightarrow$ cobbles of limgstone (atewow + whete)

$11-14 \Rightarrow$ buff brown to white sanditone with calcite deposits inni-out mivo. cystallene white powery deforits)

14-19

Pecovery $=3$ ft $\sin$

wiff bown to white stonds sandone with stwingers of dark briton lime stone b"gravel Ls@ zaft.-many pagswert sorended bultemarl last 6 in, doy, hs ì very

19-24 Recovery $=3$ ft $10 \mathrm{in}$

buft brown to white sandstone in a LSquad matrix $z$ dk brown frags -well sounded to anguear. Last 6" is angulac is grave, and staid' dry shale. is is very dense' Core bit is dahraged

24-29 Recovery = 3pt 10 in $0-2^{\prime} 4^{\prime \prime}$ \& whife to grey LS; laige cobbles of black

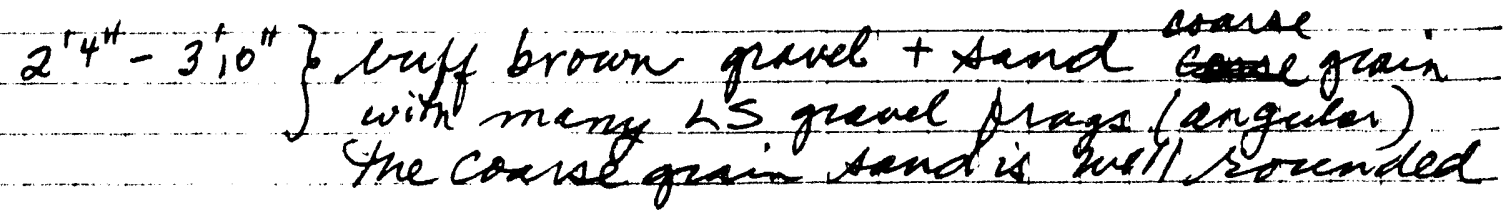

41 
$6-18-91$ mine site 4 con't

25

Depth Dexuption

29-34 tecovery $=460$ in

LS congetomerate - frage of ss, LS, shale in a tinegrain sandy matrix. One yellow $1 / 2^{\prime \prime}$ dia

Close - up photo. Bottom $3^{\prime \prime} \Rightarrow$ friable sS vifigain

$34-39$

Pecovery $=5 f$.

$0-9$ in $=$ frave SS(v.f gpain) buff red

9 in $-3 f f=$ dense red clay (diy)

$3 f t-5 f t=$ friawle SS (vifigrain) friff red

Occational white spots of calcite, v. minor

amrent of fibraus gyptien in 35

$39-44$ lecovery $=57 t$

$0-3 x^{\prime \prime} \cdot 4^{\prime \prime}$ dense red clayw/white gypsumiopots.

ift. in to $5 f t=$ friable 35 (v.f.grain)

The redclay tooks identical to that@stat

$44-49 \quad$ lecovey $=57 t$

Dense red clay w/ OCcational microcutallene gysum (white) hooks elce bal target red cles

fitted hole wf cuttings

42 
26 6-18.91 Mine Site East

Depth Sescuption Approx: 20'NE z mine"

0-4 Recovery $=3$ frsin

Dark bfown to ied clayey toud, vif. grain w/ occational is ystrags of white

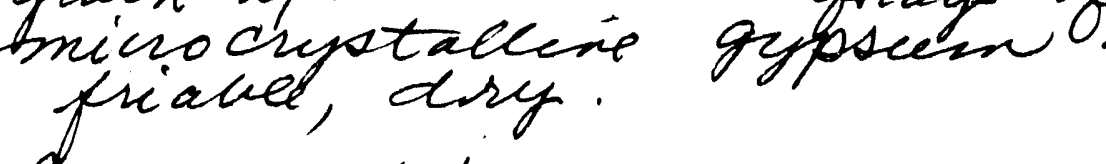

4-9 Recovery $=$ sox. Daik brow to rea claycy sand, vi, banding; ficherstallin. gypous

9-14 Recovery $=$ Sgt.

$9-10^{\prime} 4^{\prime \prime}=1$ id cleyey tand v. f.grain

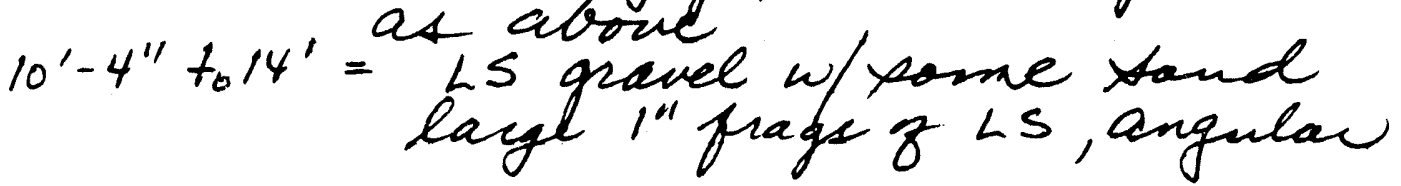

14-19 Recovery $=3 f 48$ in

is conglomerate w/ buff tond (v.f.g.)

loohs like leady $m$ il concrete wo water frianle, dry

19-24 Pecovery = 3pt10in.

19-23 3 - $\Rightarrow$ red reond serate as aboul

w/15 alove ise v.f.g. gradational contuct Q" dia gypsum, nodule at 22 gt. - whitel

microcysaceme gypsum on biff tandstone

24-29. Recovely 4 t+ Sin.

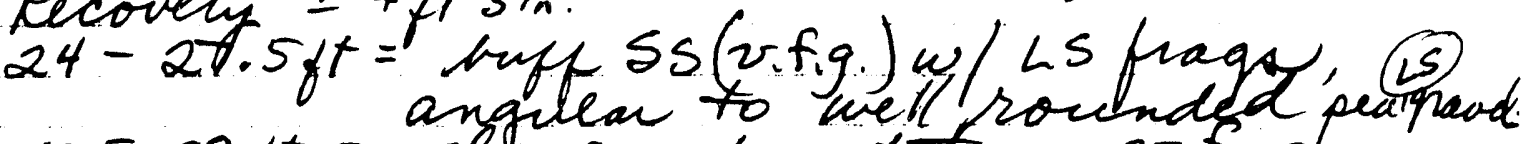

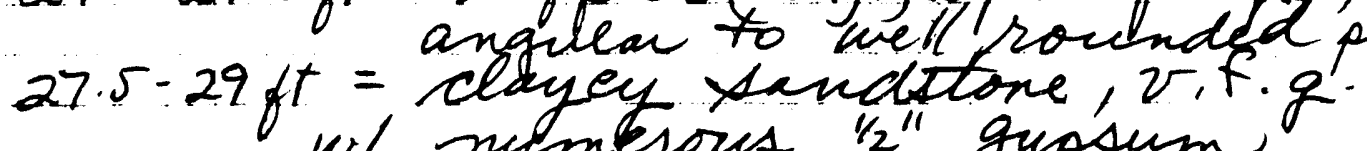

wodules

filled hale w/ cuttings

43 
10-19-91 mine Center

Depth Descuption

27

0.4 Recovery $=30$ t 6 in

Sack proun to red clayey and, vi figain

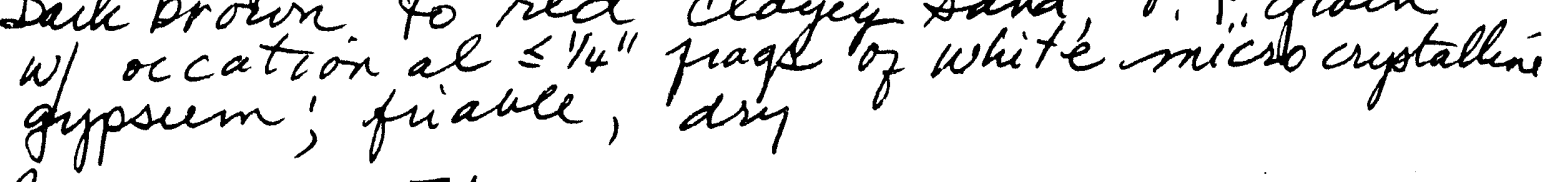

4-9 Recovery $=5$ t.

Red cleyed tand "vi"rid" grain; occational microcipta eline. ('1//4"dial gypsum spots; microcrystallere quarty thru-out friance, dry

$9-14$

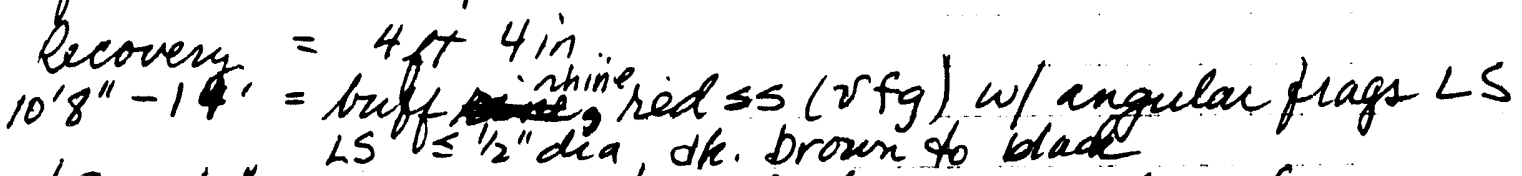

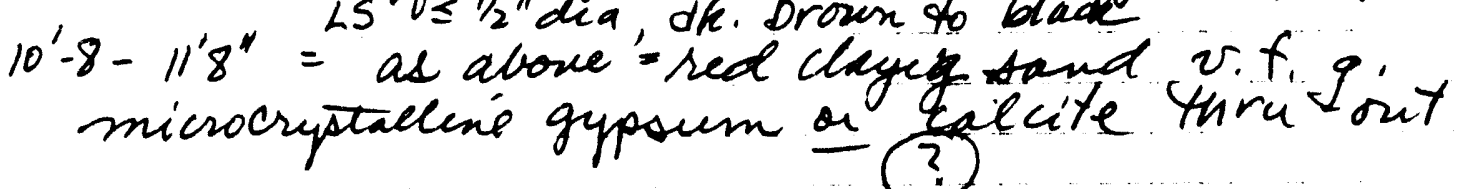

$$
\text { 14-19 Recovery }=4 f+8 \text { in }
$$

17-19 $\Rightarrow$ limey is, red (vfg) wf clay (1rift) ball frags

(L't"did); many angulan to sueff rowended

$14-17 \Rightarrow$ red clayey send vfg w/ fewer stregs and less clay than is if tee phto of core lit - a

19-24 Recovery $=3,4$ 8in

is corgeomerate $w / 2$ is $25 \%$ red ss $(v-f g)$ is + dey balls thru-out; is gravel, pea sige angulat to mell rounded. ocd ation al thale froys. All friace and dry: Contact vetween SS content de cheasing from if thru 24 while is content cincreasing

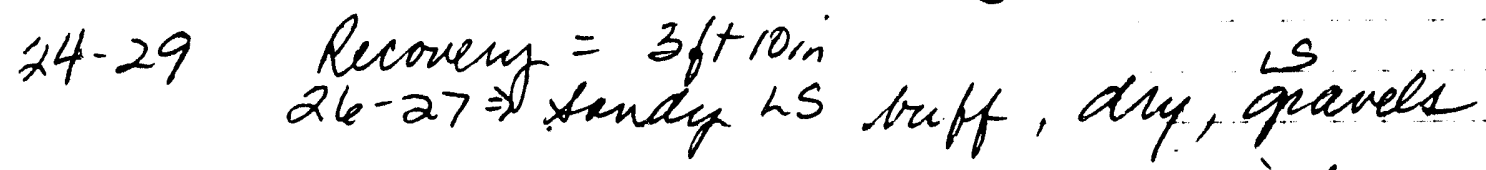

29-27 $\Rightarrow$ limey, SS, v.f.g. reddich browx of fliable dry

24-26 $\Rightarrow$ liney SS. vfg reddish brown friabledy 
28 6-19-81 Mine Central Contrnued Depti Descriteon

24-29 The 27-29' ss is more clagey than alve
mowestacky to core int.

29.34 Recovery $=3 f+8$ in

LS corglomerate-frage peubles of LS, ss, shale in avif.givantey matorite

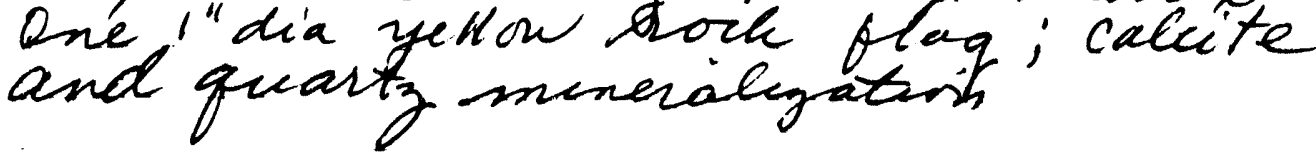

34-39 Recorery $=58 t$

Sindy hed clay w/ gypsem spots thru "nit Looks laike the top of

filled hole w/ cuttengs

45 
1-19-91 Mine site West

29

Depta sescrition

Recovery $=3 f t \sin$

Red deayed sand vfgrain w/occatooial "4". Frage of white micis crystallere gypsum fridued, diy

4-9 Recorrery = szt.

Dack red als, v. f. grain Jiavle occation al microcrystallini gypsuem, calcite, quaity in sts thru-but.

9-14 Recovery $=4 j+4$ in. $13-14=$ duch red SS, v. F.g tomewhat friable $\&^{2}$ $13-8,5^{\prime} \Rightarrow$ red to huff is or germers $v$, f grain mats ix w/ fage i-2" fig hard ank trown top 6" $\Rightarrow$ dack sed ss, vi. f green friabee

$14-19 \quad$ Recoiery $=11 t$ bin

Buff to red is gravel v. $f$ gan w/ is pea grave frabe a large 2 "dia frag irt inay have been a conse grain mudsene insead if ss) fuiale, diy 19-24 No recovery - dense is (dark red to dh brown) Plike chirty. TS,

$19-24$ 2nd try Recovery $=249$ in Limey, buft to red ss w/many paigs of friave, dry

24-29 Recovery $=3 f t$ lo in

limey SS, vf.g reddish brown to buff bothorn IfT is more clayey, wi is, SS fiage and briance, bery

46 
$30 \quad 6-19-91$ Marine West con't

sipty sescription

$$
\text { 29-34 }
$$

Recoven $=3 g t \sin$.

$32-34 \Rightarrow$ LS conglomerate, angulur frage in a v.f.g.tandy 23 matris, whithe gypserm (microosystalene); clay balle $32-29 \Rightarrow$ v. F. g. ss, buft to red; small
us pea quavel in inatink.

34- 39. Reconery $=57 t$.

top $4^{\prime \prime}=$ vfg is matrix w/ LS gravel $33^{2 / 3}-39^{\prime}=$ dark red lay, dense s' stick like salt oftarget clay.'

filled hole w/ cuttings

47 
6.20.91 Mine background

31

$\frac{\text { septh }}{0-4} \frac{\text { Descreption }}{\text { Recrery }}=3 f+6$ in

Red deagey sand vifig. triave, dry.

$2^{-4} \Rightarrow$ octational milsoriptadere white gypsem micsoryptalline, shard.

4-9 Recovery $=5 f t$.

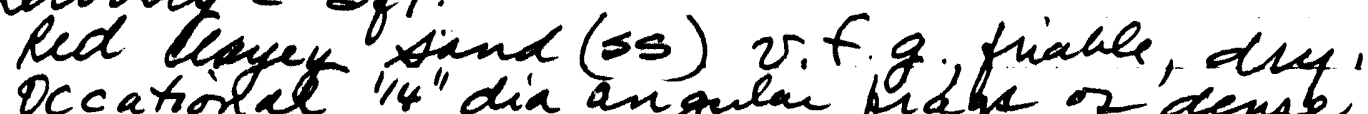

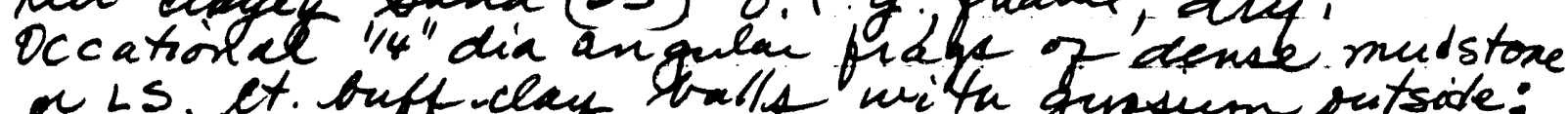
o LS, et. buff.clay bails milta ofpsum sutside;

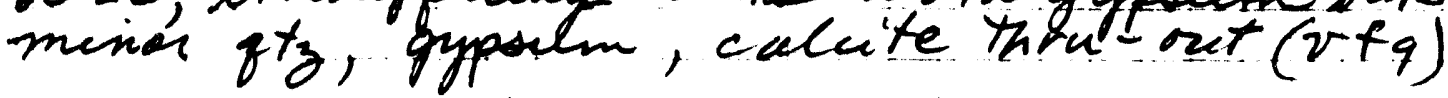

9-14 Recovecy $=4 f t 8$ in

$9-13.5^{5}=$ red clayey $56(v f q)$ fravle, dry, w/

13.5-14 $\Rightarrow$ buff to etf brown $\angle S+$ gypoum

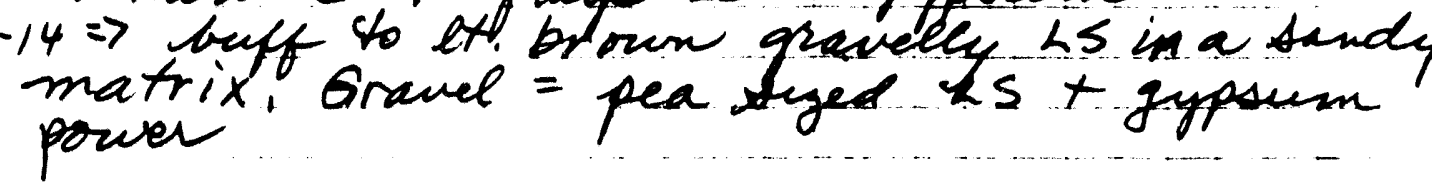

14-19 Recovery $=3$ ft 6 in

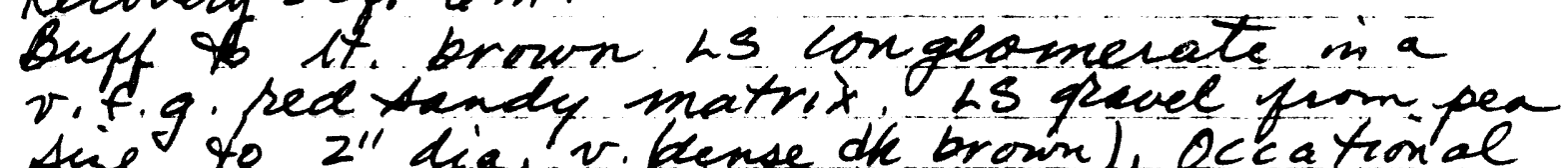
sigll to $2^{\prime \prime}$ dia. v. (lense dh brown in Occational 2 clay balls; gypsem powes thre out.

19.24 Recovery = 2ft. 4 in.

As abtue - drillinge tounds like coarse grand, Large $L S$ coubles up to $2^{\prime \prime}$ dia in core

$24-29$

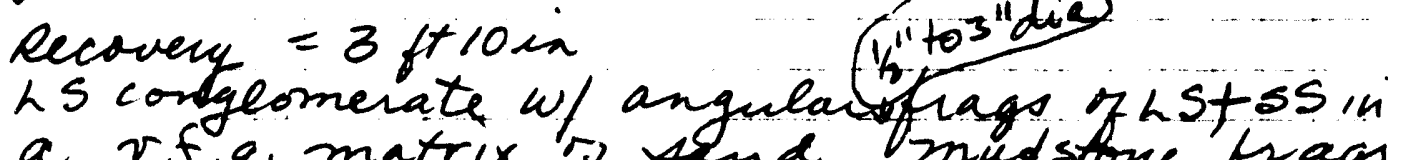
a v.f.g. matrix is and mudstone prags up to 3 "dia w/ seconday mineraluzalion

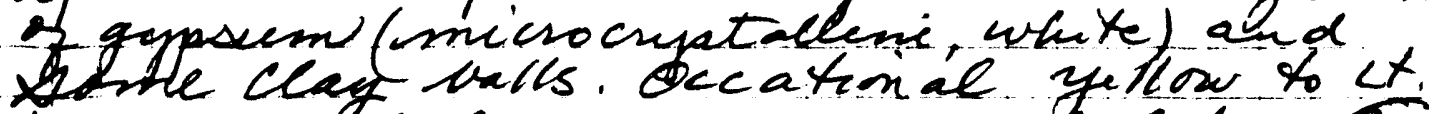
bown notules of gipsumal achepher?

$29-34$ Pecovery $=4$ froin

Buff ted SS vfg, frianle dry w/many "1/"-2" hrogs of LS jeypsimb nodules and day back in spots-ginesalex asorend peables and angle gypsem in spots-ginerally asond peables end anghearfiage

48 
32. 6-20-9) mine Background con't Syth Descuption

34-39. Reconery $=3149$ in.

Bottom "b" = Stindy, sed clay, frot real stick Top = breccia w/ "1/" to 2 "dia angular frage of LS, ss, mud stone in a thend and white gyptern nowies ephoto)

$39-44$ Recovery $=5 x$.

bense red ceay w/ accational gypsum nodules ( $\left.112^{\prime \prime}\right)$; senaier at to P a lat graditionally moe dense at bottom

44-49 fecovey = Ift

filled in hole wf cuttings

49 

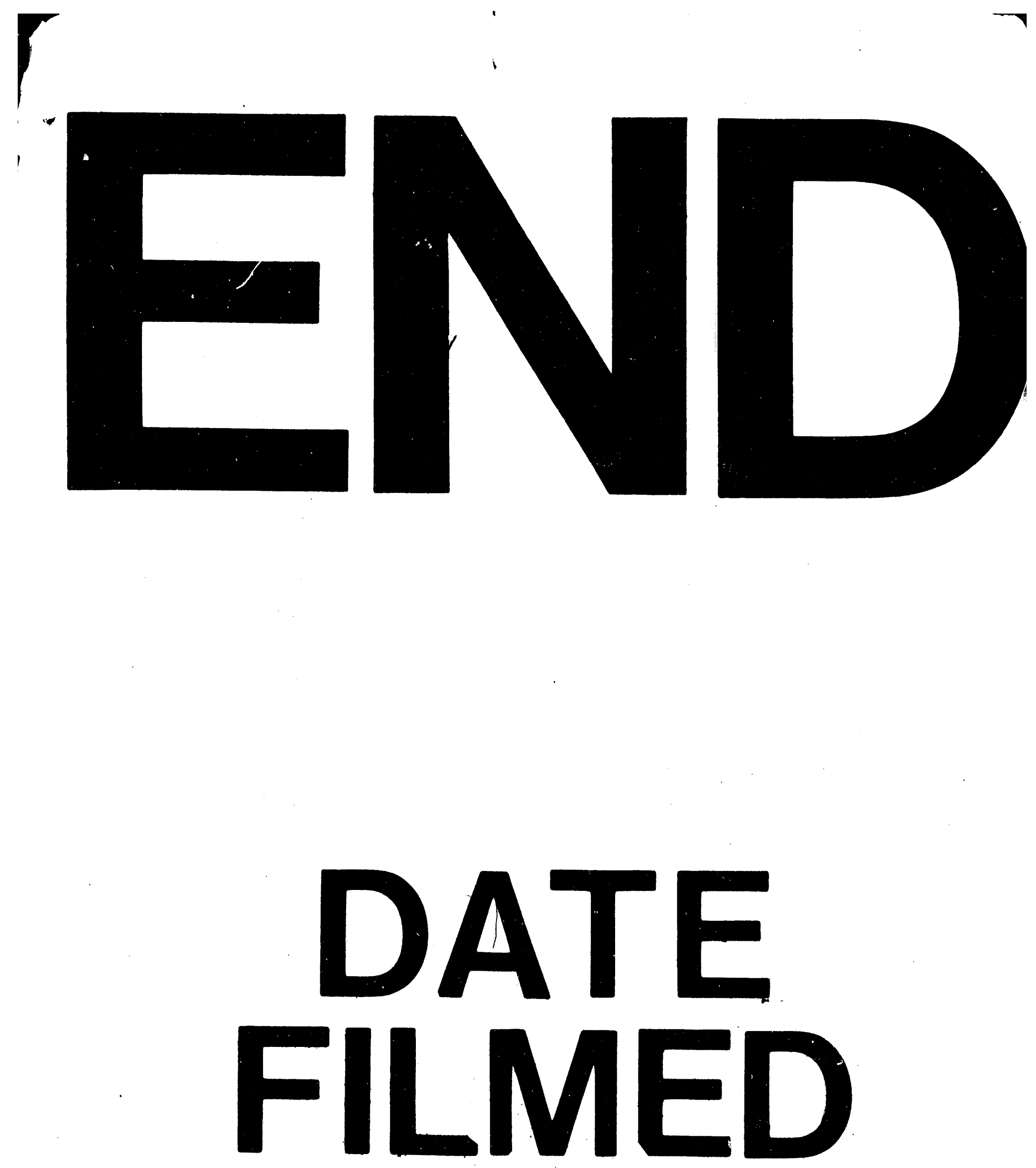

1

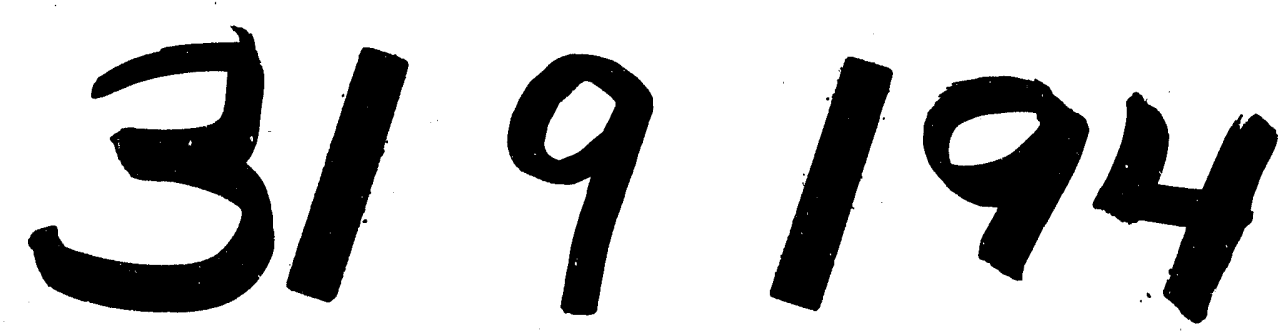


